Aquaculture

October 2017, Volume 479, Pages 176-187

http://dx.doi.org/10.1016/i.aquaculture.2017.05.046

http://archimer.ifremer.fr/doc/00387/49799/

(c) 2017 Published by Elsevier B.V.

\title{
Influence of preoperative food and temperature conditions on pearl biogenesis in Pinctada margaritifera
}

\author{
Latchere Oihana $^{1,2}$, Le Moullac Gilles ${ }^{1}$, Gaertner-Mazouni Nabila ${ }^{2}$, Fievet Julie ${ }^{1}$, Magré Kevin ${ }^{1}$, \\ Saulnier Denis ${ }^{1, *}$
}

${ }^{1}$ Ifremer, UMR 241 EIO, UPF-ILM-IRD, Labex Corail, B.P. 49, 98719 Taravao, Tahiti, French Polynesia

${ }^{2}$ Université de la Polynésie Française, UMR 241 EIO, IFREMER-ILM-IRD, Labex Corail, BP 6570, 98702 Faa'a, Tahiti, French Polynesia

*Corresponding author : Denis Saulnier, email address : Denis.Saulnier@ifremer.fr

Oihana.Latchere@ifremer.fr ; Gilles.Le.Moullac@ifremer.fr ; nabila.gaertner-mazouni@upf.pf ; Julie.Fievet@ifremer.fr ; magre.kevin@gmail.com

\begin{abstract}
:
Trophic conditions and water temperature strongly influence bivalve physiological processes and metabolism. In black-lip pearl oyster Pinctada margaritifera, these parameters have been shown to affect shell biomineralization. The present study investigated the effect of preoperative food level (i.e., microalgal concentration) and temperature on pearl biomineralization. Donor and recipient oysters were conditioned at different levels of food and temperature during the preoperative phase to evaluate the influence of these factors on 1) pearl retention rate (grafting success), 2) expression of genes involved in biomineralization in the mantle and pearl sac and 3) pearl quality traits. Our study confirmed the influence of both microalgal concentration and temperature on shell growth. Food level of donor oysters was decisive for pearl biomineralization, with donors that had been fed at a high microalgal concentration producing pearl sacs with significantly higher biomineralization capabilities and faster nacre establishment during early stages of pearl formation. However, food level showed no effects on quality traits of the pearls harvested 12 months postgrafting, while preoperative temperature only influenced the relative expression of two genes in pearl sacs at 12 months postgrafting. No significant effects of the preoperative conditioning of recipient oysters were detected in either experiment considering gene expression measurements and pearl quality traits. However, mortality was significantly lower in grafted recipient oysters fed at an intermediate trophic level. Finally, pearl weight was shown to be positively correlated with recipient oyster growth.
\end{abstract}




\section{Highlights}

- Donor oyster food level influences molecular biomineralization capabilities of pearl sacs. Donor oysters fed at a high food level produced pearls with more nacre at early stages. Recipient oyster preoperative temperature and food conditions did not affect pearl biomineralization.

Keywords : Pinctada margaritifera, Cultured pearl, Biomineralization, Environment, Gene expression, Pearl quality 


\section{Introduction}

The black-lip pearl oyster Pinctada margaritifera (Linnaeus 1758) is farmed to produce black cultured pearls - unique gems generated by a living organism - in several countries in tropical and subtropical regions. In French Polynesia, pearl production is a major industry, with the exportation of pearl products reaching 63 million Euros in 2014 (Talvard, 2016). Production sites are located in the Society, Gambier, and Tuamotu archipelagos, whose pearl production accounts for more than $95 \%$ of the world's black cultured pearls in terms of value (Cartier et al., 2012). As reported by Southgate et al. (2008a), pearl production involves four phases: (1) preoperative oyster conditioning, (2) the surgical grafting operation, (3) postoperative care, and (4) oyster culture and pearl harvest. Preoperative conditioning consists of reducing the metabolism and gametogenic activity of pearl oysters for 28-40 days prior to grafting (Aji, 2011; Gervis and Sims, 1992; Southgate et al., 2008a). Some pearl producers use preoperative conditioning, including lower water temperature, deliberate over stocking, reduction of food and oxygen levels, and placing of the pearl oysters deeper in the water column prior to the graft operation, as these actions are considered to decrease pearl rejection and improve pearl quality (Aji, 2011; Gervis and Sims, 1992; Southgate et al., 2008a). These rearing practices have not, however, been standardized nor tested under controlled conditions.

Surprisingly, the impact of the environment on cultured pearl biomineralization has been little documented, and previous studies have mainly focused on postoperative maintenance. For instance, the proportion of high-quality pearls harvested 4 months postgrafting was found to be significantly higher in recipient oysters that had undergone a low salinity treatment during the 14 days following the graft operation than in those reared conventionally (Atsumi et al., 
2014). Temperature is considered an important factor for obtaining high-quality pearls, and winter is usually considered the best season to harvest pearls. Low temperatures are believed to reduce pearl oyster metabolism and lead to thinner mineral lamellae in the final layers of nacre laid down on the pearls, thereby enhancing their luster (Alagarswami, 1987; Menzel, 1991). However, to the best of our knowledge, no study has yet examined the effect of environmental factors experienced during the preoperative conditioning period on the subsequent pearl biomineralization process. The surgical procedure known as "grafting" is carried out by skilled technicians following preoperative conditioning. A small piece of the mantle, the tissue responsible for shell mineralization, is cut from a donor oyster and inserted along with a spherical nucleus (consisting of mollusk shell or synthetic material) into the gonad of another pearl oyster, the "recipient" (Kishore and Southgate, 2016; Southgate et al., 2008a). The external epithelial cells of the graft proliferate and cover the nucleus to form a pearl sac, a process that takes approximately 30 days following the grafting operation (Cochennec-Laureau et al., 2010). The first pearl layers are not homogeneous, as they show high variability in thickness and composition, as well as a remarkable association of organic and mineral materials (Cuif et al., 2008). The basal layer of the pearl, produced by the very first secretion of the pearl sac starting 21 days postgrafting, is usually composed of thin organic layers mostly consisting of proteins, with the mineral material present as dispersed microgranules of aragonite and calcite (Cuif et al., 2011). Two months after grafting, radial microstructures perpendicular to the surface of the nucleus appear due to the formation of organic envelopes. These microstructures form prisms composed of calcite or aragonite. This prismatic aragonite is specific to pearl microstructure and has never been observed in mollusk shells. Finally, a regular and parallel nacreous layer composed of aragonite tablets is established during pearl formation. Its production may occur directly onto the organic layer or may be delayed for a few months (Cuif et al., 2011). Therefore, the mineralization capabilities 
of the graft could be critical for the development of nacreous layers during the early stages of pearl formation and for obtaining high-quality pearls.

Pearl biomineralization results from complex molecular processes. The pearl sac epithelium synthesizes shell matrix proteins (SMPs), which play a major role in pearl biomineralization. Numerous SMPs have been characterized and some genes encoding these proteins have been identified in pearl oysters (Joubert et al., 2010; Marie et al., 2012; Montagnani et al., 2011; Suzuki et al., 2009). SMPs are thought to partly regulate the formation of the prismatic and nacreous shell layers (Marie et al., 2012). Notable examples of nacreous layer-related proteins include Pif177, known to specifically bind to aragonite crystals (Suzuki et al., 2009); MSI60, which is involved in the formation of aragonite crystal (Sudo et al., 1997); and Pearlin, which exhibits calcium- and chitin-binding properties (Montagnani et al., 2011). In the prismatic layer, Aspein is involved in the calcite precipitation process (Isowa et al., 2012), while Prismalin14 plays an important role in regulating calcification of the prismatic layer (Suzuki et al., 2004). Some proteins such as Nacrein are important for shell formation and are implicated in the mineralization processes of both the aragonitic nacreous and the calcitic prismatic layers (Miyamoto et al., 2005).

Pearl production is also a complex process that involves genetic contributions from two oysters (donor and recipient), which may be affected by the environment. Although the donor oyster is primarily responsible for the expression pattern of biomineralization genes in the pearl sac at both genomic (Arnaud-Haond et al., 2007) and transcriptomic levels (McGinty et al., 2012), the recipient oyster is strongly suspected to regulate pearl sac metabolism (Le Pabic et al., 2016) The grafter skills also influence pearl biomineralization and quality (Ky et al., 2015b, 2014). Recently, significant correlations have been demonstrated between pearl 
quality traits and some donor and recipient characteristics, such as a positive correlation between pearl nacre deposition and recipient shell growth or significant donor effects on pearl nacre deposition, luster, shape and defects (McDougall et al., 2016). To date, very little attention has been paid to the effects of environmental factors on pearl biomineralization. The purpose of our study was therefore to investigate under controlled conditions the effects of food level (microalgal concentration) and temperature during the preoperative phase to test their influence on: 1) the pearl retention rate, 2) the molecular mechanism involved in biomineralization in both the mantle and pearl sac and 3) pearl quality traits.

\section{Material and Methods}

\subsection{Biological material}

Wild P. margaritifera pearl oysters aged 18 months were obtained by spat collection and transferred by air from Arutua lagoon to Vairao lagoon. These animals were then left in the lagoon for an acclimatization period of at least one month before the trophic and temperature conditioning experiments were conducted.

\subsection{Shell labeling and deposition rate}

The pearl oysters were immersed for $12 \mathrm{~h}$ in a $150 \mathrm{mg} \cdot \mathrm{L}^{-1}$ calcein (Sigma-Aldrich) solution prepared using 0.1-mm filtered seawater 5-6 days before the conditioning experiments. Both the donor and the recipient shells were sawn along the dorsoventral axis at different sampling time using a SwapTop Trim Saw (Inland, Middlesex, UK). The ventral sides of the shell cross-sections were observed by epifluorescence microscopy using a Leica DM400B microscope (I3 filter block and LAS V.8.0 software for size measurements). The shell deposit 
rate $\left(\mathrm{SDR}, \mu \mathrm{m} \cdot \mathrm{day}^{-1}\right)$ was calculated by dividing the thickness of the new nacre deposits formed during the experimental time by the number of days that had elapsed since the marking (Linard et al., 2011). A mean of two measurements was calculated for each cross section.

\subsection{Experimental design}

\subsubsection{Experiment 1: microalgal concentration conditioning experiment}

A total of 392 pearl oysters with a mean height of $10.5 \pm 0.4 \mathrm{~cm}$ and a mean weight of 157.1 $\pm 27.7 \mathrm{~g}$ were divided among eight 500 -L tanks in which microalgal concentrations were gradually increased over a period of 5 days. The pearl oysters were then reared for 30 days in April 2014. During the 1-month conditioning experiment, the pearl oysters were divided into two groups fed a mixed diet composed of two microalgae: 2/3 Tisochrysis lutea (T-iso) and 1/3 Chaetoceros gracilis, at an overall concentration of 10,000 or 40,000 cells $\cdot \mathrm{mL}^{-1}$ supplied continuously using Blackstone dosing pumps (Hanna). Tanks were sampled automatically every 3 min for fluorescence and temperature measurements. The intermediate concentration is considered as an optimal food concentration for P. margaritifera (Yukihira et al., 1998) and the high concentration is close to ingestion saturation (Le Moullac et al., 2013). During this experiment, the mean temperature was $28.1 \pm 0.5^{\circ} \mathrm{C}$. Twelve pearl oysters $(3.1 \%)$ died during the conditioning period, $10(2.6 \%)$ were not grafted at the end of conditioning because of their apparently poor health status (weak resistance of the adductor muscle prior to shell opening), 10 were used as donor oysters, and 360 were grafted (Fig. 1, see 2.4 section for a detailed description of this procedure).

\subsubsection{Experiment 2: temperature-conditioning experiment}


A total of 378 pearl oysters with a mean height of $10.8 \pm 0.5 \mathrm{~cm}$ and a mean weight of 175.4 $\pm 35.5 \mathrm{~g}$ were divided among eight $500-\mathrm{L}$ tanks in which temperatures were gradually increased or decreased over a period of 5 days. The pearl oysters were then reared for 30 days in June 2014. Then the pearl oysters were split into two groups, which were exposed to water temperatures of 22 and $30^{\circ} \mathrm{C}$, respectively. In French Polynesia, the monitoring of temperature data over 10 years (Ifremer sources) showed that water temperature is rarely lower than $22^{\circ} \mathrm{C}$ and higher than $30^{\circ} \mathrm{C}$. The lower temperature is recorded in the Gambier and Australes archipelagoes whereas the higher is recorded in the Tuamotu archipelago. During the experiment, the pearl oysters were fed a mixed diet composed of two microalgae, $2 / 3$ Tisochrysis lutea (T-iso) and 1/3 Chaetoceros gracilis at a concentration of $25,000 \mathrm{cell} \cdot \mathrm{mL}^{-1}$ supplied continuously using Blackstone dosing pumps (Hanna). Tanks were sampled automatically every $3 \mathrm{~min}$ for fluorescence and temperature measurements Seventeen pearl oysters $(4.5 \%)$ died during the temperature conditioning experiment, three $(0.8 \%)$ were not grafted because of their apparently poor health status (weak resistance of the adductor muscle prior to shell opening), 10 were used as donor oysters, and 348 were grafted (Fig.1; see 2.4 section for a detailed description of the grafting process).

\subsection{Grafting operation and sampling}

For each graft experiment, donor oyster selection was based on shell appearance and muscle resistance prior to shell opening (Tayale et al., 2012). Each recipient oyster was grafted using a 2.4 BU "Bio-coat" nucleus (7.27 mm diameter, Hyakusyo Co., Japan). For experiments 1 and 2, donor oysters were used to produce around 30 grafts. For all donors in both experiments, a single experienced grafting technician implanted almost equal numbers of 
grafts in two batches of randomly selected recipient oysters previously conditioned under differing experimental conditions (Fig. 1).

Grafted oysters were individually placed in net retention bags during the postgrafting phase, which were put in Vairao lagoon. On day 45 postgrafting, grafted oysters were evaluated for pearl retention rates (absence of rejected pearl in the retention bag) and mortalities. Those that had retained their pearls were hung on labeled chaplets (ropes). Pearl oysters were sampled at 45 days $(\mathrm{N}=60$ from each experiment), 3 months $(\mathrm{N}=60$ from each experiment), and 12 months postgrafting (this last sample consisted of all the remaining pearl oysters, $\mathrm{N}=113$ and $\mathrm{N}=166$ for the microalgal and temperature conditioning experiments, respectively). At each sampling time, 40 pearl sacs, corresponding to four grafted oysters for each combination of tested environmental condition and donor used, were randomly sampled and kept in RNAlater® (Fig. 1).

\subsection{Gene expression profiles in mantle and pearl sac tissues}

Total cellular RNA was extracted from the mantle of the donor oysters and from the pearl sacs of $P$. margaritifera at each sampling time using TRIzol reagent (Life Technologies) according to the manufacturer's recommendations. RNA was quantified using a NanoDrop ND-1000 spectrophotometer (NanoDrop Technologies Inc.). For each sample, $3 \mu \mathrm{g}$ of total RNA was treated with DNase (Ambion) to degrade any potential DNA contaminants. The expression levels of six biomineralization-related genes were analyzed using quantitative reverse transcription-polymerase chain reaction (RT-qPCR) analysis using a set of forward and reverse primers (Table 1). Three other genes out of the following were used as 
housekeeping genes: 18S rRNA (Larsen et al., 2005), glyceraldehyde 3-phosphate dehydrogenase or GAPDH (Lemer et al., 2015), and an export factor binding protein or REF1 (Joubert et al., 2014). First-strand cDNA was synthesized from 400 ng of total RNA using a Transcriptor First Strand cDNA synthesis kit (Roche) and a combination of random hexamer and oligo(dT) primers in a final reaction volume of $25 \mu \mathrm{L}$. Quantitative PCR (qPCR) amplifications were carried out on a Stratagene MX3000P using Brilliant II SYBR Green QPCR master mix (Stratagene) with $400 \mathrm{nM}$ of each primer and $10 \mu \mathrm{L}$ of 1:100 diluted cDNA template.

The qPCR reactions consisted of an initial step of 10 min at $95^{\circ} \mathrm{C}$ followed by 40 cycles $\left(95^{\circ} \mathrm{C}\right.$ for $30 \mathrm{~s}, 60^{\circ} \mathrm{C}$ for $30 \mathrm{~s}$, and $72^{\circ} \mathrm{C}$ for $\left.1 \mathrm{~min}\right)$. At the end of these steps, an additional cycle was performed from 55 to $95^{\circ} \mathrm{C}$, increasing by $0.1{ }^{\circ} \mathrm{C}$ every second, to generate the dissociation curves and verify the specificity of the PCR products. All measurements were performed on duplicate samples. Expression levels were estimated by evaluating the fluorescence signal emitted by SYBR-Green®. This fluorescent marker binds to doublestranded DNA (dsDNA) and the fluorescence emitted is proportional to the dsDNA present in the reaction mix. Calculations were based on cycle threshold $(\mathrm{Ct})$ values. The relative gene expression ratio of each biomineralization-related gene was calculated following the deltadelta method normalized to three reference genes (Livak and Schmittgen, 2001). This is defined as: ratio $=2^{-[\Delta \mathrm{Ct} \text { sample- } \Delta \mathrm{Ct} \text { calibrator }]}=2^{-\Delta \Delta \mathrm{Ct}}$, where the $\Delta \mathrm{Ct}$ sample is the $\Delta \mathrm{Ct}$ obtained for a target gene in one sample after normalization to the reference genes and the $\Delta \mathrm{Ct}$ calibrator is the mean of the $\Delta \mathrm{Ct}$ values obtained for all the six genes for each environmental factor (food level and temperature) at each sampling time. 


\subsection{Measurement of nacre deposition in the early stages of pearl}

\section{formation, pearl quality traits and deposit weight}

Nacre deposition in immature pearls, i.e., those pearls harvested at 45 days and 3 months post grafting, was classed into three categories: absence of nacre, nacre covering $<50 \%$ of the pearl surface area, and $>50 \%$ of the pearl surface area. Mature pearls, haryested at 12 months post grafting, were cleaned by ultrasonication in soapy water using an LEO 801 laboratory cleaner (2-L capacity, $80 \mathrm{~W}, 46 \mathrm{kHz}$ ) and were then rinsed in water. Four cultured pearl quality traits were determined in mature pearls: shape, surface defects, darkness, and luster. Both the nacre deposition on immature pearls and the quality traits of mature pearls were evaluated visually by two operators who examined the pearls together. The pearl deposit weight was measured using a digital balance, and the final value was calculated by subtracting the nucleus weight from the pearl weight.

\subsection{Statistical analysis}

The normality of data distribution and homogeneity of variance were tested using the ShapiroWilk and Bartlett tests, respectively. For experiment 1, the SDR data followed the conditions for application of parametric tests so the effect of microalgal concentration on SDR was tested using a Student $t$-test. For experiment 2, the SDR did not meet the conditions of application for parametric tests and could not be normalized by mathematical transformation; therefore, the effect of temperature on SDR was tested using a Mann-Whitney test. Differences in pearl retention and mortality rates of the different preoperative conditions were evaluated using Chi-square tests. The effects of preoperative conditions on nacre deposition in the early stages of pearl formation and on pearl quality traits were tested using F-tests. Due to the non- 
normality of some pearl weight deposit distributions, these values were Box-Cox transformed to satisfy the conditions for parametric tests. Differences in pearl weight deposition were tested using Student $t$-tests. Sperman's correlation coefficient was calculated to measure the strength of the relationship of pearl weight and both donor and recipient oyster growth at the $5 \%$ alpha level.

Expression values of genes that met the conditions for parametric tests were analyzed using Student $t$-tests while those that did not were tested using Mann-Whitney tests. In all cases, $\mathrm{p}$ values $\leq 0.05$ were considered statistically significant, and all data analyses were performed using XLSTAT (version 1.01, 2014).

\section{Results}

\section{Effects of microalgal concentration and temperature conditioning of future donor and recipient oysters on pearl oyster culture}

\section{traits:}

\subsection{Shell biomineralization}

Mean shell deposit rate (SDR) was measured following shell calcein marking to analyze the effect of microalgal concentration and temperature on shell growth during the preoperative conditioning phase. Donor oysters fed at 10,000 and 40,000 cells $\cdot \mathrm{mL}^{-1}$ had SDR values of 2.6 \pm 2.0 and $7.3 \pm 1.9 \mu \mathrm{m} \cdot \mathrm{day}^{-1}$ (Fig. 2A), respectively. A Student $t$-test confirmed the significant effect of microalgal concentration on SDR $(p=0.006)$. In the temperature experiment, the mean SDR was $0.8 \pm 0.4$ and $2.3 \pm 1.6 \mu \mathrm{m} \cdot$ day $^{-1}$ for donor oysters 
conditioned at 22 and $30^{\circ} \mathrm{C}$, respectively (Fig. 2B). Despite considerable variation in the SDR of pearl oysters conditioned at $30^{\circ} \mathrm{C}$, the Mann-Whitney test showed that SDR was significantly affected by temperature $(\mathrm{p}=0.037)$.

\subsection{Expression of shell matrix protein genes in mantle}

For pearl oysters conditioned at different microalgal concentrations, the relative expressions of the six biomineralization-related target genes were not significantly different (Fig. 3A). The genes MSI60, Pearlin, and Aspein were more highly expressed than the others were. Similar results were obtained for the pearl oysters conditioned at different temperatures (Fig. 3B). There were no significant differences in the relative expression levels of any of the studied genes.

\subsection{Pearl retention rate}

At 45 days postgrafting, for the food level experiment, pearl retention was between 74.2 and $85.4 \%$ and was not significantly dependent on the preoperative microalgal concentration supplied to donor or recipient pearl oysters (Table 2A). Mortality values were also independent of the preoperative microalgal concentration of donor oysters $\left(\chi^{2}, p=0.737\right)$. However, mortality values were dependent on the preoperative microalgal concentration of grafted recipient oysters: mortality was lower following intermediate microalgal conditioning $\left(\chi^{2}, p=0.038\right)$ than high microalgal conditioning. For the temperature experiment, pearl retention was between 67.0 and $73.6 \%$ and was not significantly dependent on the preoperative temperature at which donor and recipient pearl oysters had been conditioned 
(Table 2B). Mortality values were also independent of the preoperative conditioning temperature of donor $\left(\chi^{2}, \mathrm{p}=0.083\right)$ and recipient pearl oysters $\left(\chi^{2}, \mathrm{p}=0.66\right)$.

\subsection{Gene expression in the pearl sac during pearl biogenesis}

In a preliminary analysis (data not presented), we studied the expression levels of each gene for the four subgroups (combinations of the preoperative conditions of the donor and recipient oysters) for each experiment. We found no significant differences in expression levels when grafts from a given donor preoperative treatment were put in recipient oysters issued from different preoperative conditions, regardless of the genes considered and the food or temperature levels at which the donor oysters had been conditioned. Consequently, we decided to analyze the gene expression levels only as a function of the preoperative donor condition.

The three genes (Pmarg-MSI60, $\mathrm{p}=0.029$; Pmarg-Pif177, $\mathrm{p}=0.009$; and Pmarg-Pearlin, $\mathrm{p}=$ 0.05) involved in nacre formation were significantly upregulated 45 days postgrafting in pearl oysters implanted with grafts collected from the donors preoperatively fed at 40,000 cells $\cdot \mathrm{mL}^{-}$

1 (Fig. 4A.1). In addition, one gene involved in prism formation was significantly downregulated (Pmarg-Prismalin14, $\mathrm{p}=0.0002$ ). Furthermore, at 3 months postgrafting, two genes involved in prism formation were downregulated (Pmarg-Aspein, $\mathrm{p}=0.021$ and PmargPrismalin14, Fig. 4A.2, p = 0.009) while, at 12 months postgrafting, only one gene (PmargPrismalin14) was significantly downregulated (Fig. 4A.3, $p=0.017$ ). There were no significantly different effects with donor preoperative conditioning temperature at 45 days or 3 months postgrafting (Fig. 4B.1 and B.2). At 12 months postgrafting (Fig. 4B.3), two genes 
were significantly upregulated in pearl oysters implanted with grafts collected from donors preconditioned at $30^{\circ} \mathrm{C}$ (Pmarg-Pif177, $\mathrm{p}=0.014$ and Pmarg-Nacrein A1, $\mathrm{p}=0.013$ ).

\subsection{Nacre deposition quality}

At 45 days postgrafting, nacre deposition differed significantly depending on donor preoperative microalgal concentration (F-test, $\mathrm{p}=0.038$, Fig. 5A.1). Furthermore, donor oysters fed 10,000 cells $\cdot \mathrm{mL}^{-1}$ gave rise to a significantly lower proportion of pearls in the nacre $>50 \%$ category, whereas those fed 40,000 cells $\cdot \mathrm{mL}^{-1}$ produced a significantly lower proportion of pearls without nacre than would be expected by chance. At 3 months postgrafting, nacre deposition was significantly dependent on the preoperative microalgal concentration fed to the donor oysters (F-test, $\mathrm{p}=0.05$, Fig. 5A.2). Donor oysters preconditioned at 10,000 cells $\cdot \mathrm{mL}^{-1}$ produced a significantly higher proportion of pearls without nacre than expected by chance. In contrast, donor oysters preconditioned at 40,000 cells $\cdot \mathrm{mL}^{-1}$ produced a significantly lower proportion of pearls without nacre and significantly higher proportion of the nacre $>50 \%$ category than would be expected by chance. The preoperative microalgal concentration supplied to recipient oysters showed no effects on any group at 45 days or 3 months postgrafting (results not shown).

In the temperature experiment, no significant effects of donor preoperative conditions were observed on nacre deposition at 45 days or 3 months postgrafting (F-test, $\mathrm{p}=0.264$ and $\mathrm{p}=$ 0.306, Fig. 6B.1 and B.2, respectively). Furthermore, the preoperative conditioning temperature of recipient oysters showed no significant effects on nacre deposition at 45 days or 3 months postgrafting (results not shown). 
The quality of pearls harvested at 12 months post grafting was evaluated using four criteria: shape, number of defects, darkness, and luster (Fig. 6). The microalgal concentration used for donor oysters did not significantly affect the shape $(\mathrm{p}=0.707)$, number of defects $(\mathrm{p}=0.188)$, darkness $(p=0.119)$, or luster $(p=0.810)$. Similarly, the temperature at which donor oysters were conditioned did not significantly affect pearl shape $(p=0.108)$, number of defects $(p=$ $0.830)$, darkness $(\mathrm{p}=0.051)$, or luster $(\mathrm{p}=0.409)$. For recipient oyster conditioning, neither microalgal concentration nor temperature treatments had any significant effects on pearl quality criteria (results not shown).

\subsection{Pearl deposit weight}

For pearl oysters with grafts collected from donor oysters fed 10,000 cells $\cdot \mathrm{mL}^{-1}$, the mean pearl deposit weight was $0.08 \pm 0.03,0.19 \pm 0.1$, and $0.77 \pm 0.28 \mathrm{~g}$ at 45 days, 3 months, and 12 months postgrafting, respectively (Fig. 7A). For pearl oysters with grafts collected from donor oysters fed 40,000 cells $\cdot \mathrm{mL}^{-1}$, the mean pearl deposit weight was $0.07 \pm 0.03,0.19 \pm$ 0.08 , and $0.66 \pm 0.27 \mathrm{~g}$ at 45 days, 3 months, and 12 months postgrafting, respectively (Fig. 7A). Mean pearl deposit weight showed no significant difference according to donor microalgal conditioning level at any of the sampling times (45 days, $\mathrm{p}=0.392 ; 3$ months, $\mathrm{p}=$ 0.775; and 12 months, $\mathrm{p}=0.052$ ). Pearl weight was positively correlated with recipient SDR at 45 days and 3 months postgrafting whereas it was not significantly correlated with donor SDR (Table 3A). 
Donor oysters maintained at $22^{\circ} \mathrm{C}$ during the preoperative phase produced pearls whose mean deposit weights were $0.07 \pm 0.03,0.20 \pm 0.09$, and $0.65 \pm 0.25 \mathrm{~g}$ at 45 days, 3 months, and 12 months postgrafting, respectively (Fig. 7B). Donor preconditioning at $30^{\circ} \mathrm{C}$ led to pearls whose mean deposit weights were $0.05 \pm 0.03,0.17 \pm 0.08$, and $0.57 \pm 0.21 \mathrm{~g}$ at 45 days, 3 months, and 12 months postgrafting, respectively (Fig. 7B). Mean pearl deposit weight showed no significant difference according to donor temperature conditioning at any of the sampling times (45 days, $\mathrm{p}=0.128 ; 3$ months, $\mathrm{p}=0.290$; and 12 months, $\mathrm{p}=0.098$ ). Pearl weight was positively correlated with recipient SDR at 45 days, 3 months and 12 months postgrafting whereas it was not significantly correlated with donor SDR (Table 3B).

For recipient preoperative conditions, neither microalgal concentration nor temperature had a significant effect on pearl deposit weight at any of the sampling times (results not shown).

\section{Discussion}

Our objective was to determine, under controlled conditions, the influence of food level (microalgal concentration) and temperature during the preoperative phase of pearl biogenesis. We analyzed pearl retention rate, expression level of biomineralization-related genes in the pearl sac and pearl quality traits. Our results suggest that, among the preoperative conditioning factors tested, food level has the greatest impact on pearl biogenesis. Indeed, donor oysters fed at high microalgal levels led to pearls sacs with higher biomineralization capabilities and faster nacre establishment during early stages of pearl formation. Surprisingly, we found no significant effect of recipient conditioning in any of the analyses. However, recipient oyster growth at different sampling time was positively correlated to pearl 
weight for both experiments. As recipient oysters are strongly suspected to regulate pearl sac metabolism, it would be of interest to test the influence of food level and temperature on pearl biogenesis during the postgrafting phase.

\subsection{Effect of food level and temperature on shell biomineralization}

The physiological process and metabolism of bivalves are mostly controlled by two environmental factors, temperature and food (Kanazawa and Sato, 2008; Laing, 2000; Schöne et al., 2005, 2003; Thébault et al., 2008). In pearl oysters, these two parameters affect growth, reproduction, and biomineralization (Joubert et al., 2014; Southgate et al., 2008b; Teaniniuraitemoana et al., 2015). After only 1 month of conditioning, we found that both microalgal concentration and temperature affected pearl oyster shell growth. In our experiments, SDR was 2.8 times higher at 40,000 cells $\cdot \mathrm{mL}^{-1}$ than it was at 10000 cells $\cdot \mathrm{mL}^{-1}$, and was 2.9 times higher at $30^{\circ} \mathrm{C}$ than it was at $22^{\circ} \mathrm{C}$. Our results corroborate those of previous studies showing the effect of microalgal concentration (Linard et al., 2011) and microalgal concentration and temperature combined (Joubert et al., 2014) on P. margaritifera SDR. Moreover, Le Moullac et al. (2016) reported that temperature affected the metabolic rate of the pearl oyster $P$. margaritifera and demonstrated an energy gain from 22 to $30^{\circ} \mathrm{C}$, at which metabolic rates were maximized. The energy gain might explain why we observed higher SDR at $30^{\circ} \mathrm{C}$ than at $22^{\circ} \mathrm{C}$.

Biomineralization is an energetically costly process, and the synthesis of organic matrix proteins requires higher energy than does the precipitation of mineralized components (Palmer, 1983). However, our study revealed no significant effect of either food level or 
temperature on biomineralization related genes encoding proteins involved in the formation of nacreous and prismatic layers in the mantle of donor oysters. These results do not correspond to those of Joubert et al. (2014), who reported an upregulation of Pmarg-Pif177 and a downregulation of Pmarg-MSI60 in the mantle of pearl oysters by comparing the effects of two food levels. However, in this previous study, microalgal concentrations were lower than the levels used in the present one ( 800 vs. 15,000 cells $\cdot \mathrm{mL}^{-1}$ ) and the experiment was longer (2 months). Regarding temperature, our results are consistent with those of Le Moullac et al. (2016), who showed that the expression level of some of our target genes, such as PmargAspein and Pmarg-Nacrein A1, were not significantly different between 22 and $30^{\circ} \mathrm{C}$. Nevertheless, we cannot exclude an effect of intermediate temperatures between 22 and $30^{\circ} \mathrm{C}$. Indeed, a significant downregulation of these latter two genes was shown at $30^{\circ} \mathrm{C}$ compared to levels recorded at $26^{\circ} \mathrm{C}$ (Le Moullac et al., 2016). Finally, the panel of biomineralizationrelated genes selected in the present study may not be sufficiently sensitive to detect a significant response to the tested temperatures. With the advent of high-throughput sequencing technologies, an overall analysis without a priori knowledge, such as RNA-Seq, would enable the identification of differentially expressed genes related to biomineralization.

\subsection{Effect of food level and temperature on pearl retention and}

\section{mortality}

Achieving high retention rates and low mortality following the grafting operation is essential for the pearl production industry. The microalgal concentrations in the preconditioning treatments of this study did not significantly affect pearl retention rate, and the temperature treatments did not significantly affect either pearl retention rate or mortality. The retention and mortality rates we obtained for our two graft experiments were in the same range as the 
values reported by Ky et al. $(2013,2015)$. However, we found significantly lower mortality at 45 days postgrafting for recipient oysters that had been fed at the intermediate microalgal concentration than for those that had been fed at the higher microalgal concentration. The reason for pearl oyster mortality following the graft operation is not clear. However, Cochennec-Laureau et al. (2010) examined histological sections of gonads of grafted pearl oysters (P. margaritifera) that died following graft operations and found evidence of strong inflammatory reaction. They also pointed out that when mature gonads are incised for nucleus implantation, many gametes are released around the implanted graft. In our study, we hypothesize that grafted recipient oysters fed at intermediate microalgal concentration may have less cellular debris such as gametes around the graft, which could reduce the risk of postoperative infections. However, histological studies are needed to confirm this hypothesis.

\subsection{Pearl sac biomineralization capabilities}

In order to avoid donor oyster's effect on pearl biomineralization (Arnaud-Haond et al., 2007; McGinty et al., 2012; Tayale et al., 2012), care was taken to split grafts from each donor oyster across the two treatments for each experiment. The profile of gene expression in the pearl sac of recipient oysters was similar to that of donor oysters in the corresponding microalgal preoperative conditions, regardless of the sampling time. The pearl sacs from donor oysters fed at high concentration of microalgae showed significant overexpression of the three genes related to nacre formation (Pmarg-MSI60, Pmarg-Pif177 and Pmarg-Pearlin) and a downregulation of one gene related to prismatic layer formation (Pmarg-Prismalin14) at 45 days postgrafting, compared to the pearl sacs from donor oysters fed at intermediate microalgal concentration. We also observed significant downregulation of Pmarg-Prismalin14 and Pmarg-Aspein at 3 months postgrafting, and significant downregulation of Pmarg- 
Prismalin14 at 12 months postgrafting. Prismalin14 plays an important role in the regulation of calcification of the prismatic layer (Suzuki et al., 2004), and Aspein is involved in the calcite precipitation process (Isowa et al., 2012). The pearl sacs that originated from the mantle tissue of donor oysters fed at high microalgal concentration may produce fewer prisms than the pearl sacs obtained from donor oysters fed at intermediate microalgal concentration. Conversely, the grafts originating from donors fed at high microalgal concentration showed higher biomineralization capabilities than those from donors fed at intermediate microalgal concentration. Interestingly, Sato et al. (2013) showed that MSI60 was strongly expressed at 38 days postgrafting in the pearl sacs of oysters producing pearls with nacreous layers, whereas it was not expressed in pearls exhibiting prismatic layers. In the latter study, the authors hypothesized that, after a transition phase between prismatic and nacreous layers during pearl formation, the nacreous layer formation observed in typical nacreous pearl is associated with strong MSI60 expression during the early stages of pearl formation. Moreover, Pmarg-Pif177 was shown to be positively correlated with pearl nacre weight and thickness (Blay et al., 2016). Inoue et al. (2011a) reported gene expression patterns of shell matrix proteins (including four genes in common with our study: MSI60, Nacrein, Prismalin14, and Aspein) in the mantle graft and pearl sacs harvested 4, 10, 15, and 48 days after implantation. They showed that gene expression pattern changes before and after pearl sac formation. They hypothesized that gene expression patterns are closely related to the type of layer formed on the nucleus (nacreous or prismatic layer) and may be regulated by the donor oyster (Inoue et al., 2011a). Moreover, McGinty et al. (2012) used a xenograft between two different pearl oyster species and showed that the donor mantle tissue (rather than recipient tissue) is the main contributor to the expression of biomineralization genes believed to be involved in pearl formation. 
In the temperature experiment, no significant differences in the gene expression of the pearl sac were detected at 45 days or 3 months postgrafting. Surprisingly, at 12 months postgrafting, two genes (Pmarg-Pif177 and Pmarg-Nacrein A1) were upregulated for pearl oysters whose grafts originated from donor oysters conditioned at $30^{\circ} \mathrm{C}$ temperature compared to those conditioned at $22^{\circ} \mathrm{C}$ during the month preceding the graft. The reason why differentially expressed genes were only detected 12 months postgrafting has not been elucidated, but Pmarg-Pif177 and Pmarg-Nacrein A1 showed little expression 45 days and 3 months postgrafting and may be preferentially involved during the latter stages of pearl formation.

Irrespective of the sampling time and experiment, Pmarg-MSI60 was one of the most highly expressed genes, in agreement with the work of Inoue et al. (Inoue et al., 2011b) who showed that MSI60 expression was higher than that of Nacrein and a "prismatic-layer-forming" gene on pearl sac from $P$. fucata harvested 2 months postgrafting.

\subsection{Effect of microalgal concentration and temperature on nacre deposition in early stages of pearl formation and on pearl quality}

Nacre deposition on the pearl during the early stages of its formation was significantly dependent at both 45 days and 3 months postgrafting on the microalgal concentration at which donor oysters had been conditioned. In general, the donor oysters fed at the high food level produced pearls with a significantly higher proportion of nacre at 45 days and 3 months postgrafting. These results are consistent with the gene expression measurements in the corresponding pearl sacs (see section 4.3). The pearl oysters whose grafts originated from donor oysters fed at a high microalgal concentration may have higher biomineralization capabilities, resulting in the faster appearance of nacre on the nucleus during pearl formation. The establishment of the nacreous layer may occur directly on the organic layer and can 
appear some months later (Cuif et al., 2011). Our results indicate that donor oyster food level during conditioning may be critical for pearl sac biomineralization capabilities and nacreous layer establishment. In their study, McGinty et al. (2010) showed that mantle grafts from different pearl oyster species influenced the rate of pearl nacre deposition and pearl nacre weight differently following a xenograft between $P$. margaritifera and $P$. maxima. In our study, we detected both a molecular signature and the dependence of nacre establishment on donor oyster preoperative conditioning.

In contrast, the temperature at which donor oysters were conditioned had no effect on pearl nacre deposition. This environmental parameter may have more influence on the molecular processes involved in pearl biomineralization and consequently pearl quality traits during the latter stages of pearl formation than before nucleus implantation (Alagarswami, 1987; Menzel, 1991). In addition, we showed no significant effect of the preoperative growing conditions of recipient oysters on any of the parameters measured in either of the experiments. As recipient oysters are strongly suspected to regulate pearl sac metabolism, it would be interesting to study the influence of food level and temperature during the postgrafting phase on pearl biogenesis.

Ultimately, we did not detect any differences in pearl quality 12 months postgrafting according to donor or recipient preoperative conditions. Pearl shape has been shown to be dependent on grafter skill (Jerry et al., 2012) and suspected to be influenced by the morphology of the gonad (Southgate et al., 2008a). In our study, a single professional grafter performed all the grafts to minimize the former effect. Pearl luster and darkness may also be linked to the ultrastructure of the pearl's later nacreous layers. Indeed, some pearl producers prefer to harvest pearls during late autumn or winter when temperatures are lower, as this is 
thought to improve the quality of pearl luster by reducing growth and making the layers of nacre thinner (Alagarswami, 1987; Menzel, 1991). In our study, we did not find any effect of donor or recipient preoperative environmental conditions on pearl weight at any of the sampling times in either experiment. However, recipient oyster growth at different sampling time was positively correlated with pearl weight for both experiments. This is in agreement with previous studies showing positive correlation between pearl nacre thickness and recipient shell thickness, height and width (Le Pabic et al., 2016) and between cultured pearl size parameters and some characteristics of the recipient oyster (shell height, total weight, and shell weight) in P. fucata martensii (Wang et al., 2013). Some pearl parameters such as weight and nacre deposition rate might be under the control of the recipient oysters, with pearl sac metabolism regulated through the food supply.

\section{Conclusions}

In this study, we confirmed that microalgal concentration and temperature affect $P$. margaritifera shell growth. High temperatures and food level $\left(30^{\circ} \mathrm{C}\right.$ and 40,000 cells $\cdot \mathrm{mL}^{-1}$ of a mixed diet of 2/3 T isochrysis lutea (T-iso) and 1/3 Chaetoceros gracilis respectively) enhanced $P$. margaritifera growth rate. Stimulating this growth rate and thus reaching a size suitable for graft operation more rapidly would be beneficial to pearl industry. Nevertheless, a particular care should be taken for the preoperative conditioning of future recipient oysters since we evidenced lower mortality following graft operation for recipient oysters that had been fed during one month at the intermediate microalgal concentration of 10,000 cells $\cdot \mathrm{mL}^{-1}$ (2/3 T isochrysis lutea (T-iso) and 1/3 Chaetoceros gracilis). In contrast, the preoperative conditioning of future donor oyster at high food level increased both significantly the nacrerelated gene expression in pearl sacs and nacre establishment during the early stages of pearl biogenesis. Furthermore, we did not detect any effect of recipient conditioning on gene 
expression or pearl characteristics in either experiment. All these combined results taken together, key recommandations for pearl industry should be to use high and intermediate trophic levels for the preoperative oyster conditioning phase culture of future donor and recipient oysters respectively. Further study is needed to test whether the environment influences recipient oysters after the graft by modulating their metabolism and whether this could impact pearl biomineralization.

\section{Acknowledgements}

This study was supported by grants from Ifremer, the Direction des Ressources Marines et Minières, and private partners through the TripaGEN project (2015-2017). The authors are indebted to the "Pommier" pearl farm (Arutua) for providing the biological material and for performing the experimental grafts at Vairao. Authors are also grateful to the Ifremer staff in charge of algae production and zootechny : Manaarii Sham Koua, Mayalen Maihota and Nono Lewis Tetaura. 


\section{References}

Aji, L.P., 2011. An overview of the method, management, problem and their solution in the pearl oyster (Pinctada margaritifera) culture. J. Coast. Dev. 14, 181-190.

Alagarswami, K., 1987. Cultured pearls-production and quality. C. Bull. 39, 107-111.

Arnaud-Haond, S., Goyard, E., Vonau, V., Herbaut, C., Prou, J., Saulnier, D., 2007. Pearl formation: Persistence of the graft during the entire process of biomineralization. Mar. Biotechnol. 9, 113-116. doi:10.1007/s10126-006-6033-5

Atsumi, T., Ishikawa, T., Inoue, N., Ishibashi, R., Aoki, H., Abe, H., Kamiya, N., Komaru, A., 2014. Post-operative care of implanted pearl oysters Pinctada fucata in low salinity seawater improves the quality of pearls. Aquaculture 422-423, 232-238. doi:10.1016/j.aquaculture.2013.12.022

Blay, C., Parrad, S., Cabral, P., Aiho, V., Ky, C.L., 2016. Correlations between cultured pearl size parameters and PIF-177 biomarker expression in Pinctada margaritifera families reared in two contrasting environments. Estuar. Coast. Shelf Sci. 182, 254-260. doi:10.1016/j.ecss.2016.05.020

Cartier, L.E., Krzemnicki, M.S., Ito, M., 2012. Cultured pearl farming and production 48, 108-122.

Cochennec-Laureau, N., Montagnani, C., Saulnier, D., Fougerouse, A., Levy, P., Lo, C., 2010. A histological examination of grafting success in pearl oyster Pinctada margaritifera in French Polynesia. Aquat. Living Resour. 23, 131-140. doi:10.1051/alr/2010006

Cuif, J.-P., Ball, A.D., Dauphin, Y., Farre, B., Nouet, J., Perez-Huerta, A., Salomé, M., Williams, C.T., 2008. Structural, mineralogical, and biochemical diversity in the lower part of the pearl layer of cultivated seawater pearls from Polynesia. Microsc. Microanal. 14, 405-17. doi:10.1017/S1431927608080859

Cuif, J.-P., Dauphin, Y., Howard, L., Nouet, J., Rouzière, S., Salomé, M., 2011. Is the pearl layer a reversed shell? A re-examination of the theory of pearl formation through physical characterizations of pearl and shell developmental stages in Pinctada margartifera. Aquat. Living Resour. 24, 411-424. doi:10.1051/alr/2011048

Gervis, M.H., Sims, N.A., 1992. The Biology and Culture of Pearl Oysters (Bivalvia: Pteriidae), ICLARM Studies and Reviews. doi:10.1016/0044-8486(84)90078-4

Inoue, N., Ishibashi, R., Ishikawa, T., Atsumi, T., Aoki, H., Komaru, A., 2011a. Gene expression patterns in the outer mantle epithelial cells associated with pearl sac formation. Mar. Biotechnol. 13, 474-483. doi:10.1007/s10126-010-9318-7

Inoue, N., Ishibashi, R., Ishikawa, T., Atsumi, T., Aoki, H., Komaru, A., 2011b. Can the quality of pearls from the japanese pearl oyster (Pinctada fucata) be explained by the gene expression patterns of the major shell matrix proteins in the pearl sac? Mar. Biotechnol. 13, 48-55. doi:10.1007/s10126-010-9267-1

Isowa, Y., Sarashina, I., Setiamarga, D.H.E., Endo, K., 2012. A comparative study of the shell matrix protein Aspein in pterioid bivalves. J. Mol. Evol. 75, 11-18. doi:10.1007/s00239012-9514-3

Jerry, D.R., Kvingedal, R., Lind, C.E., Evans, B.S., Taylor, J.J.U., Safari, A.E., 2012. Donoroyster derived heritability estimates and the effect of genotype $\times$ environment interaction on the production of pearl quality traits in the silver-lip pearl oyster, Pinctada maxima. Aquaculture 338-341, 66-71. doi:10.1016/j.aquaculture.2012.02.001

Joubert, C., Linard, C., Le Moullac, G., Soyez, C., Saulnier, D., Teaniniuraitemoana, V., Ky, C.L., Gueguen, Y., 2014. Temperature and food influence shell growth and mantle gene expression of shell matrix proteins in the pearl oyster Pinctada margaritifera. PLoS One 9, 1-9. doi:10.1371/journal.pone.0103944 
Joubert, C., Piquemal, D., Marie, B., Manchon, L., Pierrat, F., Zanella-Cléon, I., CochennecLaureau, N., Gueguen, Y., Montagnani, C., 2010. Transcriptome and proteome analysis of Pinctada margaritifera calcifying mantle and shell: focus on biomineralization. BMC Genomics 11, 613. doi:10.1186/1471-2164-11-613

Kanazawa, T., Sato, S., 2008. Environmental and physiological controls on shell microgrowth pattern of Ruditapes philippinarum (Bivalvia: Veneridae) from Japan. J. Molluscan Stud. 74, 89-95. doi:10.1093/mollus/eym049

Kishore, P., Southgate, P.C., 2016. A detailed description of pearl-sac development in the black-lip pearl oyster, Pinctada margaritifera (Linnaeus 1758). Aquac. Res. 47, 22152226. doi:10.1111/are.12674

Ky, C.-L., Blay, C., Sham-Koua, M., Vanaa, V., Lo, C., Cabral, P., 2013. Family effect on cultured pearl quality in black-lipped pearl oyster Pinctada margaritifera and insights for genetic improvement. Aquat. Living Resour. 26, 133-145. doi:10.1051/alr/2013055

Ky, C.L., Molinari, N., Moe, E., Pommier, S., 2014. Impact of season and grafter skill on nucleus retention and pearl oyster mortality rate in Pinctada margaritifera aquaculture. Aquac. Int. 22, 1689-1701. doi:10.1007/s10499-014-9774-6

Ky, C.L., Blay, C., Aiho, V., Cabral, P., Le Moullac, G., Lo, C., 2015a. Macro-geographical differences influenced by family-based expression on cultured pearl grade, shape and colour in the black-lip "pearl oyster" Pinctada margaritifera: A preliminary bi-local case study in French Polynesia. Aquac. Res. 1-13. doi:10.1111/are.12880

Ky, C.L., Nakasai, S., Molinari, N., Devaux, D., 2015b. Influence of grafter skill and season on cultured pearl shape, circles and rejects in Pinctada margaritifera aquaculture in Mangareva lagoon. Aquaculture 435, 361-370. doi:10.1016/j.aquaculture.2014.10.014

Laing, I., 2000. Effect of temperature and ration on growth and condition of king scallop (Pecten maximus) spat. Aquaculture 183, 325-334. doi:10.1016/S0044-8486(99)00262-8

Larsen, J.B., Frischer, M.E., Rasmussen, L.J., Hansen, B.W., 2005. Single-step nested multiplex PCR to differentiate between various bivalve larvae. Mar. Biol. 146, 11191129. doi:10.1007/s00227-004-1524-2

Le Moullac, G., Soyez, C., Latchere, O., Vidal-Dupiol, J., Fremery, J., Saulnier, D., Lo Yat, A., Belliard, C., Mazouni-Gaertner, N., Gueguen, Y., 2016. Pinctada margaritifera responses to temperature and $\mathrm{pH}$ : Acclimation capabilities and physiological limits. Estuar. Coast. Shelf Sci. 182, 261-269. doi:10.1016/j.ecss.2016.04.011

Le Moullac, G., Soyez, C., Sham-Koua, M., Levy, P., Moriceau, J., Vonau, V., Maihota, M., Cochard, J.C., 2013. Feeding the pearl oyster Pinctada margaritifera during reproductive conditioning. Aquac. Res. 44, 404-411. doi:10.1111/j.1365-2109.2011.03045.x

Le Pabic, L., Parrad, S., Sham Koua, M., Nakasai, S., Saulnier, D., Devaux, D., Ky, C.L., 2016. Culture site dependence on pearl size realization in Pinctada margaritifera in relation to recipient oyster growth and mantle graft biomineralization gene expression using the same donor phenotype. Estuar. Coast. Shelf Sci. 182, 294-303. doi:10.1016/j.ecss.2016.03.009

Lemer, S., Saulnier, D., Gueguen, Y., Planes, S., 2015. Identification of genes associated with shell color in the black-lipped pearl oyster, Pinctada margaritifera. BMC Genomics 16, 568. doi:10.1186/s12864-015-1776-x

Linard, C., Gueguen, Y., Moriceau, J., Soyez, C., Hui, B., Raoux, A., Cuif, J.P., Cochard, J.C., Le Pennec, M., Le Moullac, G., 2011. Calcein staining of calcified structures in pearl oyster Pinctada margaritifera and the effect of food resource level on shell growth. Aquaculture 313, 149-155. doi:10.1016/j.aquaculture.2011.01.008

Livak, K.J., Schmittgen, T.D., 2001. Analysis of relative gene expression data using real-time quantitative PCR and. Methods 25, 402-408. doi:10.1006/meth.2001.1262

Marie, B., Joubert, C., Tayalé, A., Zanella-Cléon, I., Belliard, C., Piquemal, D., Cochennec- 
Laureau, N., Marin, F., Gueguen, Y., Montagnani, C., 2012. Different secretory repertoires control the biomineralization processes of prism and nacre deposition of the pearl oyster shell. Proc. Natl. Acad. Sci. U. S. A. 109, 20986-91. doi:10.1073/pnas.1210552109

McDougall, C., Moase, P., Degnan, B.M., 2016. Host and donor influence on pearls produced by the silver-lip pearl oyster, Pinctada maxima. Aquaculture 450, 313-320. doi:10.1016/j.aquaculture.2015.08.008

McGinty, E.L., Evans, B.S., Taylor, J.U.U., Jerry, D.R., 2010. Xenografts and pearl production in two pearl oyster species, $P$. maxima and $P$. margaritifera: Effect on pearl quality and a key to understanding genetic contribution. Aquaculture 302, 175-181. doi:10.1016/j.aquaculture.2010.02.023

McGinty, E.L., Zenger, K.R., Jones, D.B., Jerry, D.R., 2012. Transcriptome analysis of biomineralisation-related genes within the pearl sac: Host and donor oyster contribution. Mar. Genomics 5, 27-33. doi:10.1016/j.margen.2011.08.006

Menzel, W., 1991. Estuarine and Marine Bivalve Mollusk Culture, FL: CRC Press, Boca Raton.

Miyamoto, H., Miyoshi, F., Kohno, J., 2005. The carbonic anhydrase domain protein nacrein is expressed in the epithelial cells of the mantle and acts as a negative regulator in calcification in the mollusc Pinctada fucata. Zoolog. Sci. 22, 311-5. doi:JST.JSTAGE/zsj/22.311 [pii]

Montagnani, C., Marie, B., Marin, F., Belliard, C., Riquet, F., Tayalé, A., Zanella-Cléon, I., Fleury, E., Gueguen, Y., Piquemal, D., Cochennec-Laureau, N., 2011. Pmarg-pearlin is a matrix protein involved in nacre framework formation in the pearl oyster Pinctada margaritifera. ChemBioChem 12, 2033-2043. doi:10.1002/cbic.201100216

Palmer, A.R., 1983. Relative cost of producing skeletal organic matrix versus calcification: evidence from marine gastropods. Mar. Biol. 75, 287-292.

Sato, Y., Inoue, N., Ishikawa, T., Ishibashi, R., Obata, M., Aoki, H., Atsumi, T., Komaru, A., 2013. Pearl Microstructure and Expression of Shell Matrix Protein Genes MSI31 and MSI60 in the Pearl Sac Epithelium of Pinctada fucata by In Situ Hybridization. PLoS One 8. doi:10.1371/journal.pone.0052372

Schöne, B.R., Houk, S.D., Castro, A.D.F., Fiebig, J., Oschmann, W., Kroncke, I., Dreyer, W., Gosselck, F., 2005. Daily Growth Rates in Shells of Arctica islandica: Assessing Subseasonal Environmental Controls on a Long-lived Bivalve Mollusk. Palaios 20, 78-92. doi:10.2110/palo.2003.p03-101

Schöne, B.R., Tanabe, K., Dettman, D.L., Sato, S., 2003. Environmental controls on shell growth rates and $\delta 180$ of the shallow marine bivalve mollusk Phacosoma japonicum in Japan. Mar Biol 142, 473-485. doi:10.1007/s00227-002-0970-y

Southgate, P.C., Lucas, J.S., Lucas, J.S., 2008a. Chapter 6 - Environmental Influences, in: The Pearl Oyster. pp. 187-229. doi:10.1016/B978-0-444-52976-3.00006-1

Southgate, P.C., Lucas, J.S., Taylor, J., Strack, E., 2008b. Chapter 8 - Pearl Production, in: The Pearl Oyster. pp. 273-302. doi:10.1016/B978-0-444-52976-3.00008-5

Sudo, S., Fujikawa, T., Nagakura, T., Ohkubo, T., Sakaguchi, K., Tanaka, M., Nakashima, K., Takahashi, T., 1997. Structures of mollusc shell framework proteins. Nature 387, 563564. doi:10.1038/42391

Suzuki, M., Murayama, E., Inoue, H., Ozaki, N., Tohse, H., Kogure, T., Nagasawa, H., 2004. Characterization of Prismalin-14, a novel matrix protein from the prismatic layer of the Japanese pearl oyster (Pinctada fucata). Biochem. J. 382, 205-13. doi:10.1042/BJ20040319

Suzuki, M., Saruwatari, K., Kogure, T., Yamamoto, Y., Nishimura, T., Kato, T., Nagasawa, H., 2009. An acidic matrix protein, Pif, is a key macromolecule for nacre formation. 
Science 325, 1388-1390. doi:10.1126/science.1173793

Talvard, C., 2016. Bilan La perle en 2015, Points forts de la Polynésie française - Institut de la statistique de la Polynésie française.

Tayale, A., Gueguen, Y., Treguier, C., Le Grand, J., Cochennec-Laureau, N., Montagnani, C., Ky, C.-L., 2012. Evidence of donor effect on cultured pearl quality from a duplicated grafting experiment on Pinctada margaritifera using wild donors. Aquat. Living Resour. 25, 269-280. doi:10.1051/alr/2012034

Teaniniuraitemoana, V., Leprêtre, M., Levy, P., Vanaa, V., Parrad, S., Gaertner-Mazouni, N., Gueguen, Y., Huvet, A., Le Moullac, G., 2015. Effect of temperature, food availability, and estradiol injection on gametogenesis and gender in the pearl oyster Pinctada margaritifera. J. Exp. Zool. A. Ecol. Genet. Physiol. 13-24. doi:10.1002/jez.1992

Thébault, J., Thouzeau, G., Chauvaud, L., Cantillánez, M., Avendaño, M., 2008. (Mollusca: Bivalvia) on a natural bank in Northern Chile: sclerochronological record and environmental controls. Aquat. Living Resour. 21, 45-55. doi:10.1051/alr:2008021

Wang, S.Y., Xin, H.Z., Zhifeng, G., Aimin, W., 2013. The Influence of Saibo Donor and Host on the Nacre Deposits of Pearls Produced from Pinctada fucata martensii. J. Shellfish Res. 32, 271-274. doi:10.2983/035.032.0204

Yukihira, H., Klumpp, D.W., Lucas, J.S., 1998. Comparative effects of microalgal species and food concentration on suspension feeding and energy budgets of the pearl oysters $P$. margaritifera and P. maxima (Bivalvia: Pteriidae). Mar. Ecol. Prog. Ser. 171, 71-84. doi:10.3354/meps 171071 
Experiment 1: microalgae concentration

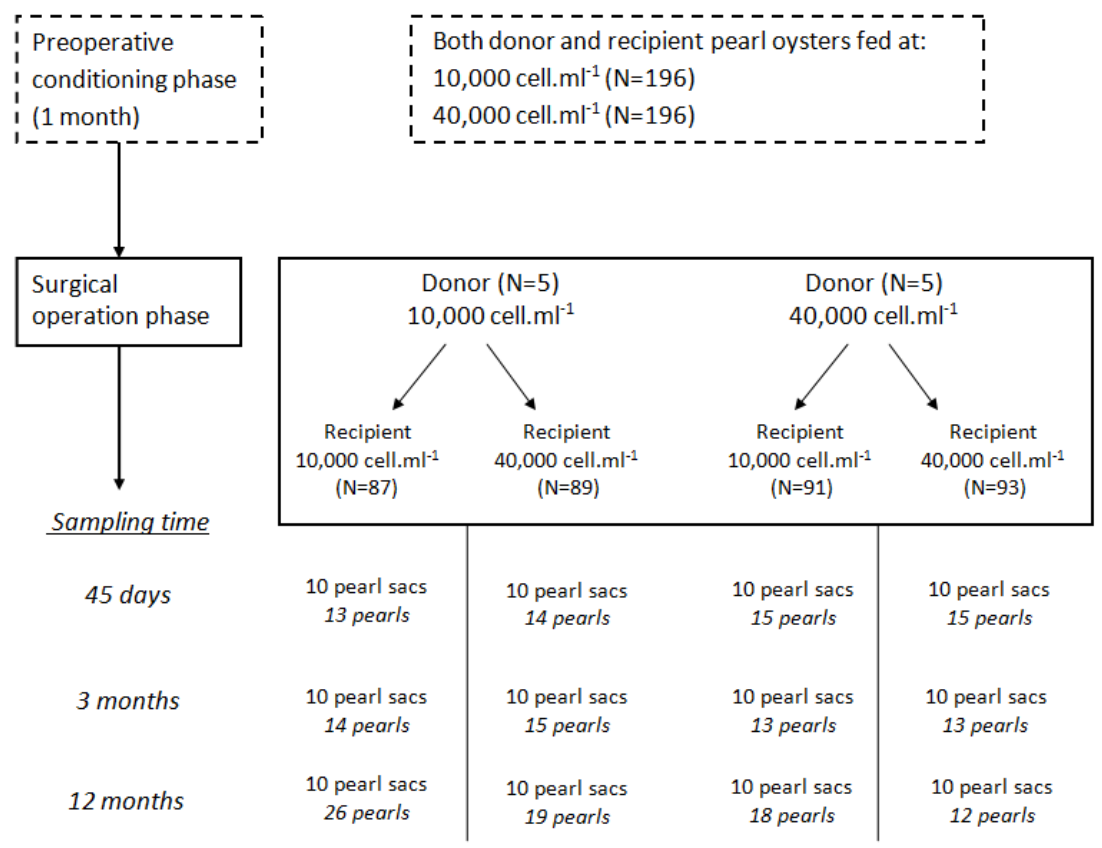

Experiment 2: temperature

Both donor and recipient pearl oysters conditioned at: $22^{\circ} \mathrm{C}(\mathrm{N}=189)$

$30^{\circ} \mathrm{C}(\mathrm{N}=189)$

\begin{tabular}{|c|c|c|c|}
\hline \multicolumn{2}{|c|}{$\begin{array}{c}\text { Donor }(\mathrm{N}=5) \\
22^{\circ} \mathrm{C}\end{array}$} & \multicolumn{2}{|c|}{$\begin{array}{c}\text { Donor }(\mathrm{N}=5) \\
30^{\circ} \mathrm{C}\end{array}$} \\
\hline $\begin{array}{c}\text { Recipient } \\
22^{\circ} \mathrm{C} \\
(\mathrm{N}=86)\end{array}$ & $\begin{array}{c}\text { Recipient } \\
30^{\circ} \mathrm{C} \\
(\mathrm{N}=87)\end{array}$ & $\begin{array}{c}\text { Recipient } \\
22^{\circ} \mathrm{C} \\
(\mathrm{N}=88)\end{array}$ & $\begin{array}{c}\text { Recipient } \\
30^{\circ} \mathrm{C} \\
(\mathrm{N}=87)\end{array}$ \\
\hline $\begin{array}{c}10 \text { pearl sacs } \\
10 \text { pearls }\end{array}$ & $\begin{array}{c}10 \text { pearl sacs } \\
12 \text { pearls }\end{array}$ & $\begin{array}{c}10 \text { pearl sacs } \\
15 \text { pearls }\end{array}$ & $\begin{array}{c}10 \text { pearl sacs } \\
15 \text { pearls }\end{array}$ \\
\hline $\begin{array}{c}10 \text { pearl sacs } \\
10 \text { pearls }\end{array}$ & $\begin{array}{c}10 \text { pearl sacs } \\
10 \text { pearls }\end{array}$ & $\begin{array}{c}10 \text { pearl sacs } \\
10 \text { pearls }\end{array}$ & $\begin{array}{c}10 \text { pearl sacs } \\
10 \text { pearls }\end{array}$ \\
\hline $\begin{array}{l}10 \text { pearl sacs } \\
27 \text { pearls }\end{array}$ & $\begin{array}{c}10 \text { pearl sacs } \\
30 \text { pearls }\end{array}$ & $\begin{array}{l}10 \text { pearl sacs } \\
29 \text { pearls }\end{array}$ & $\begin{array}{c}10 \text { pearl sacs } \\
26 \text { pearls }\end{array}$ \\
\hline
\end{tabular}

Fig. 1. 
A
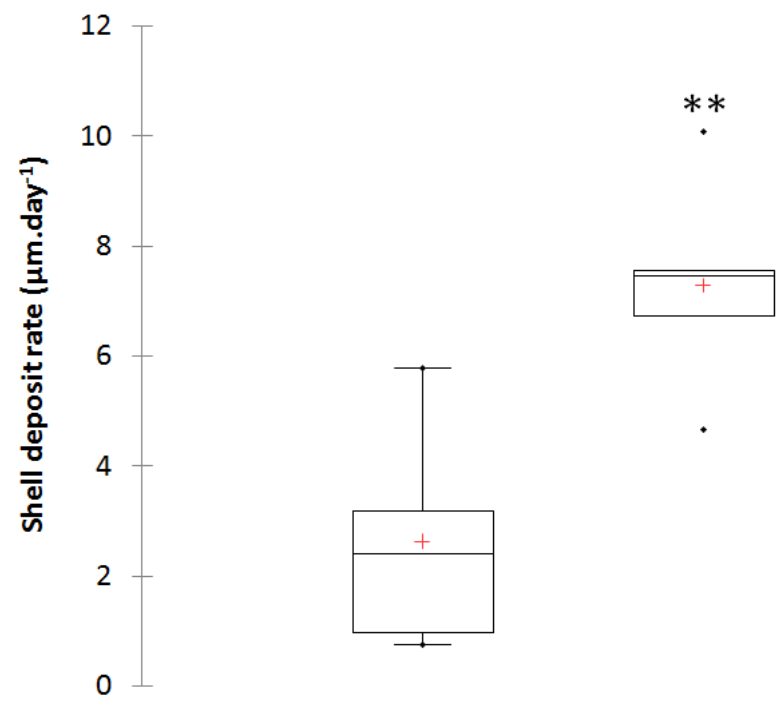

B

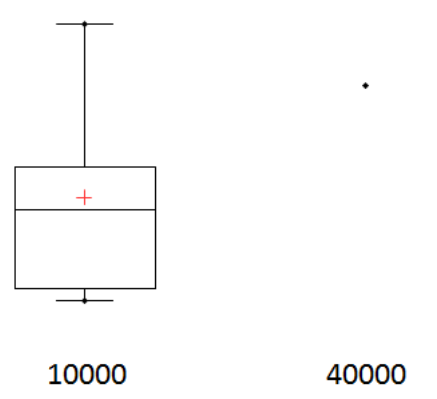

Microalgal concentration (cell.ml-1)
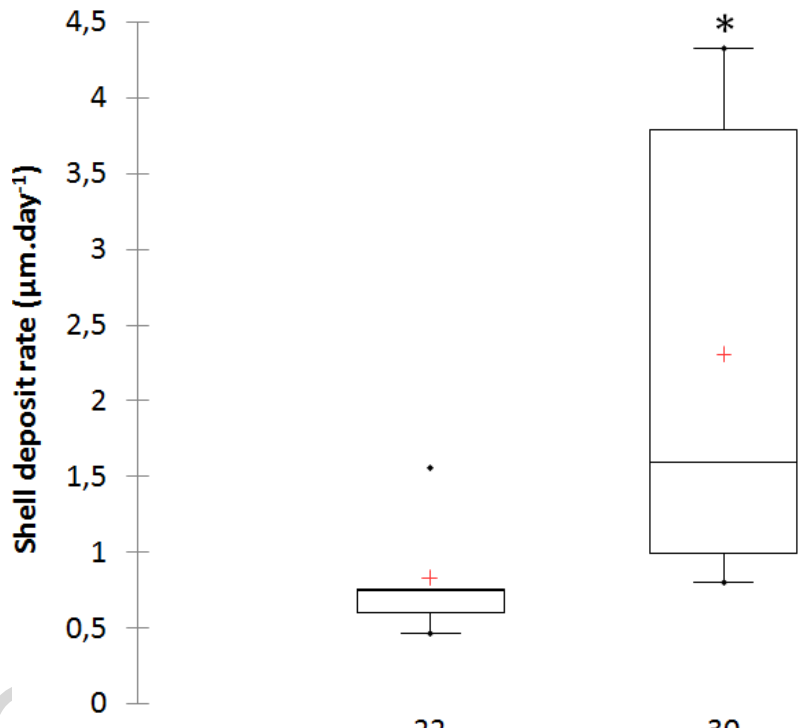

22

30

Temperature $\left({ }^{\circ} \mathrm{C}\right)$

Fig. 2. 
A

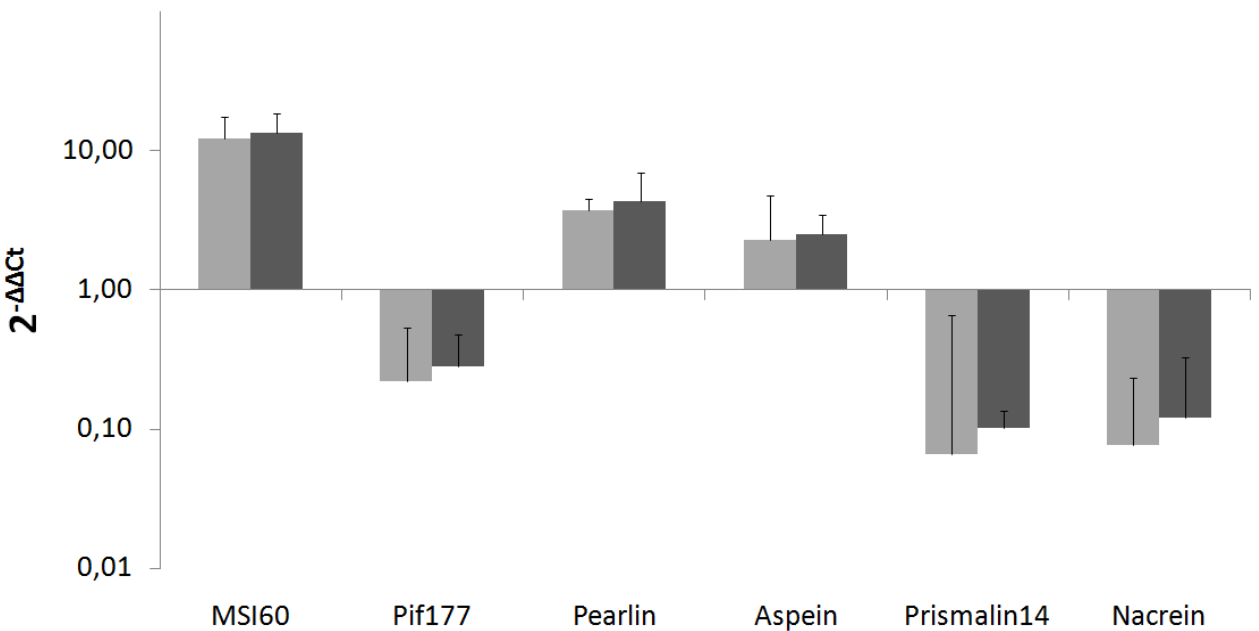

B

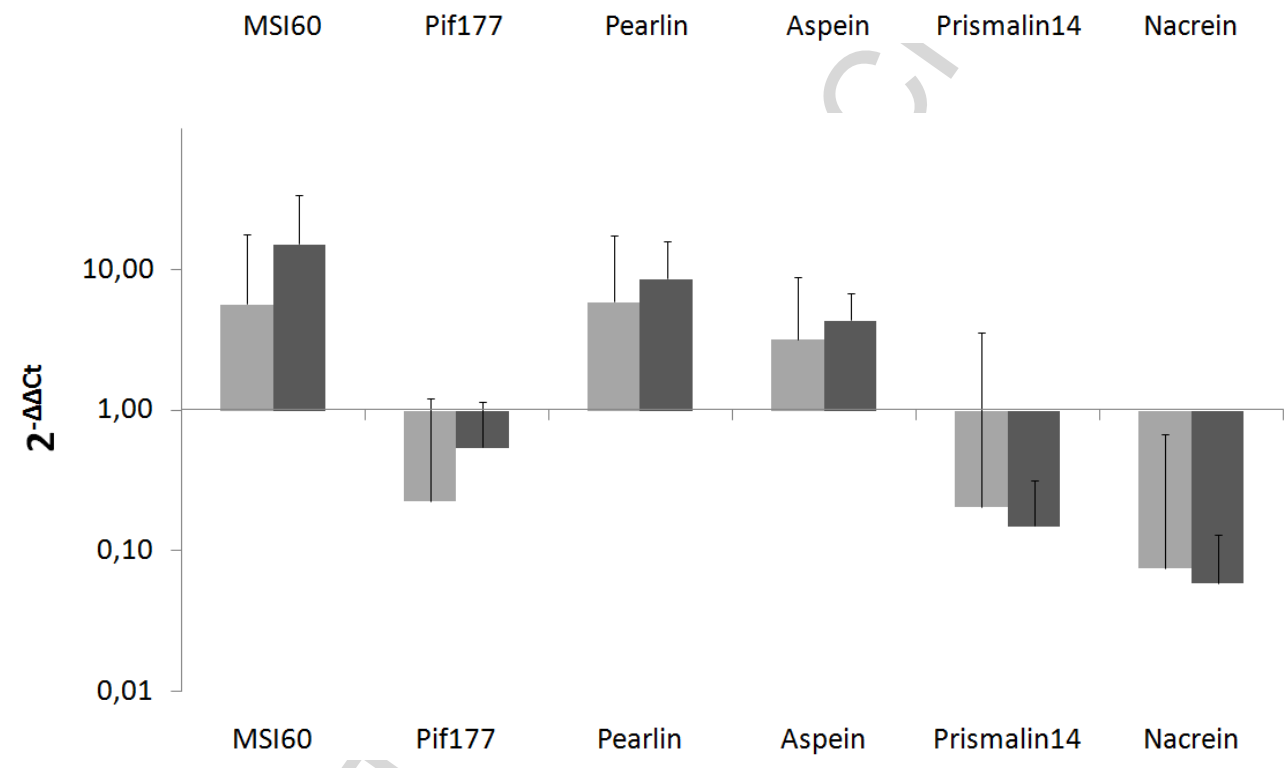

Fig. 3. 
A. 1

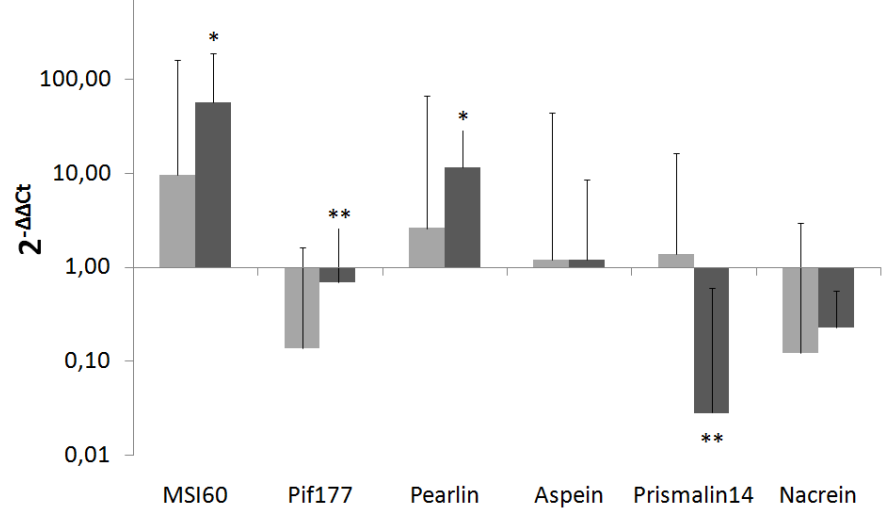

A. 2

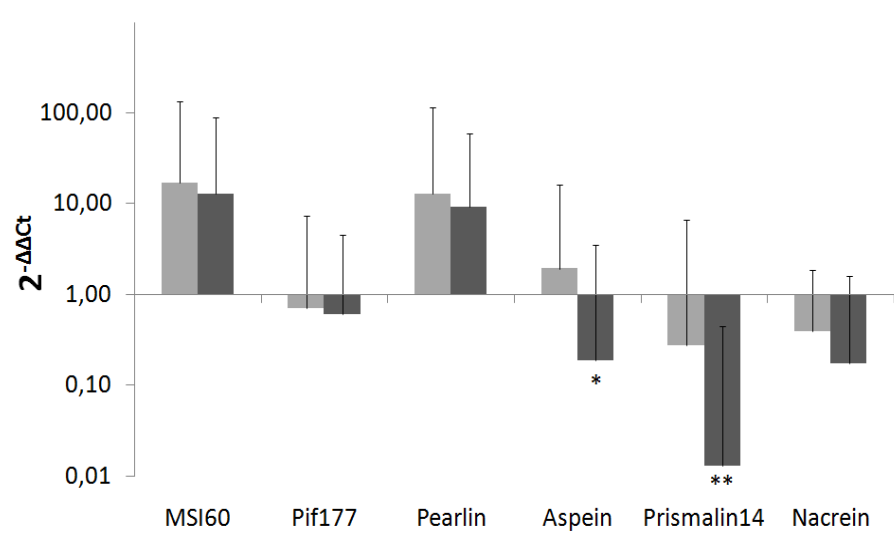

A. 3

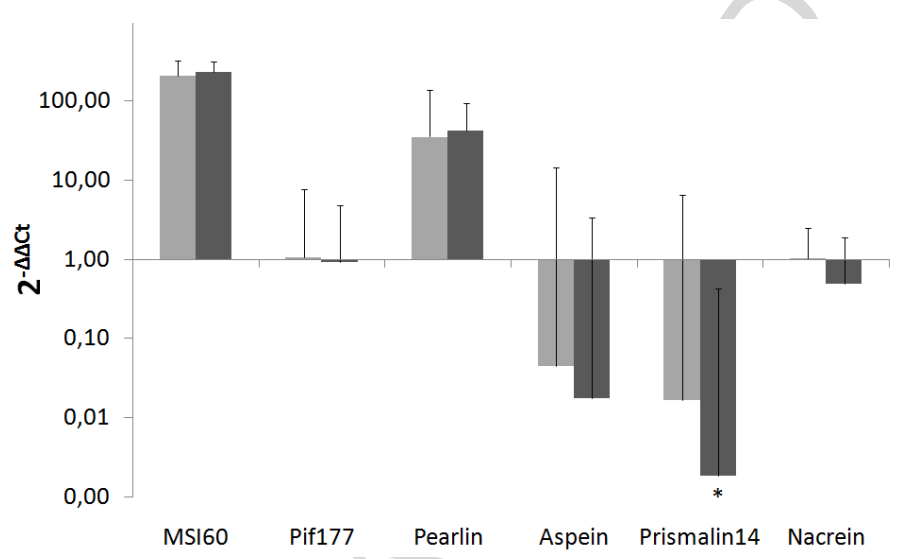

B. 1

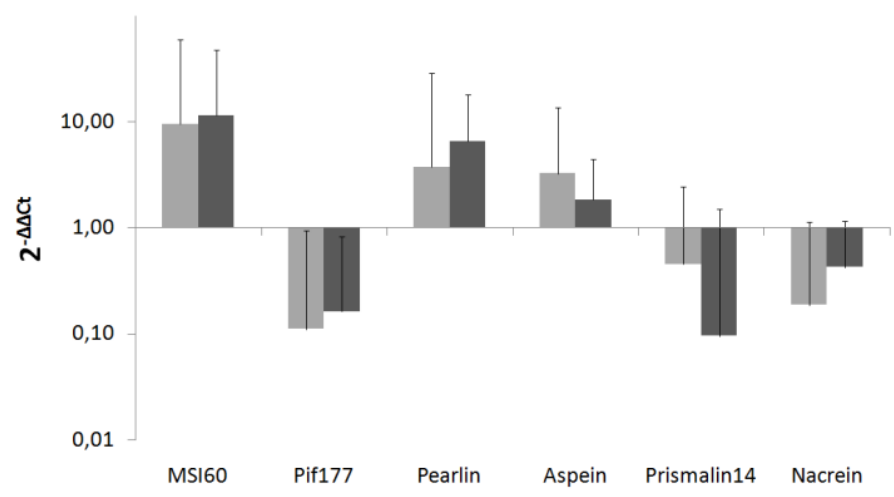

B. 2

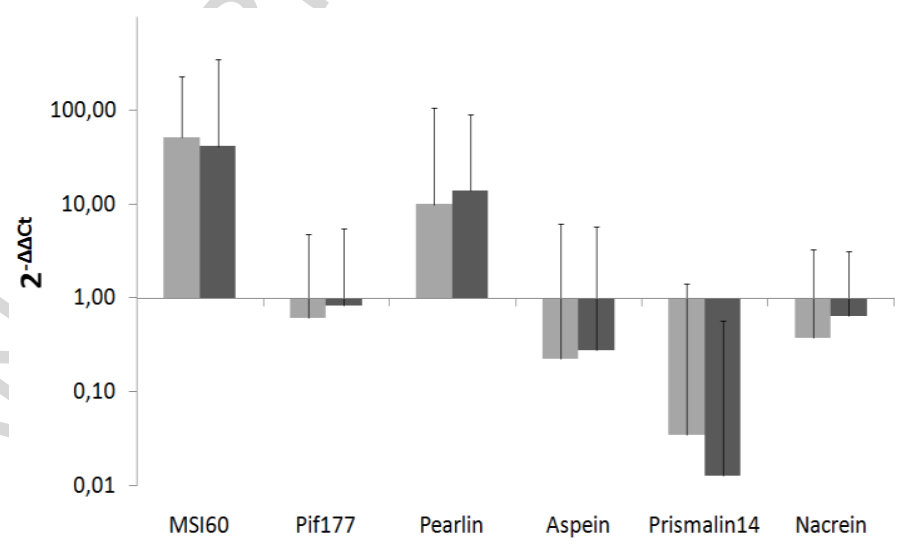

B. 3

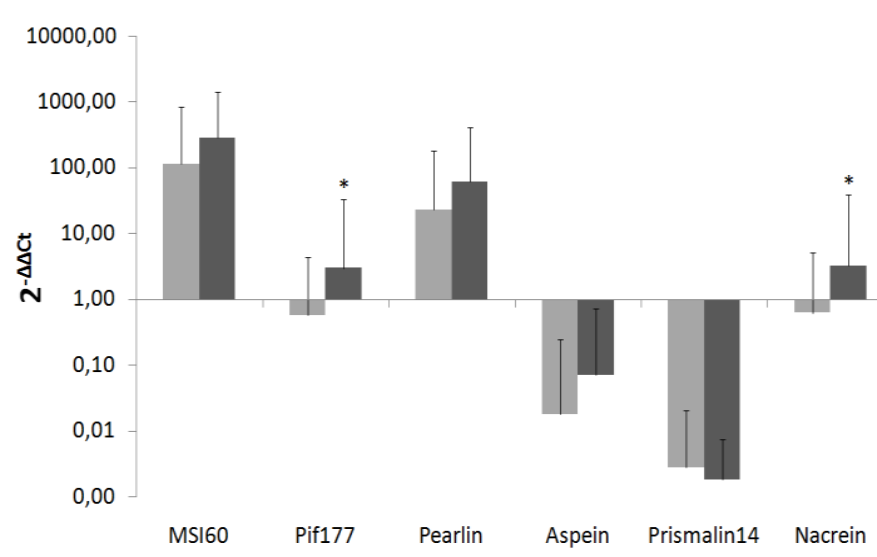

Fig. 4. 
A.1

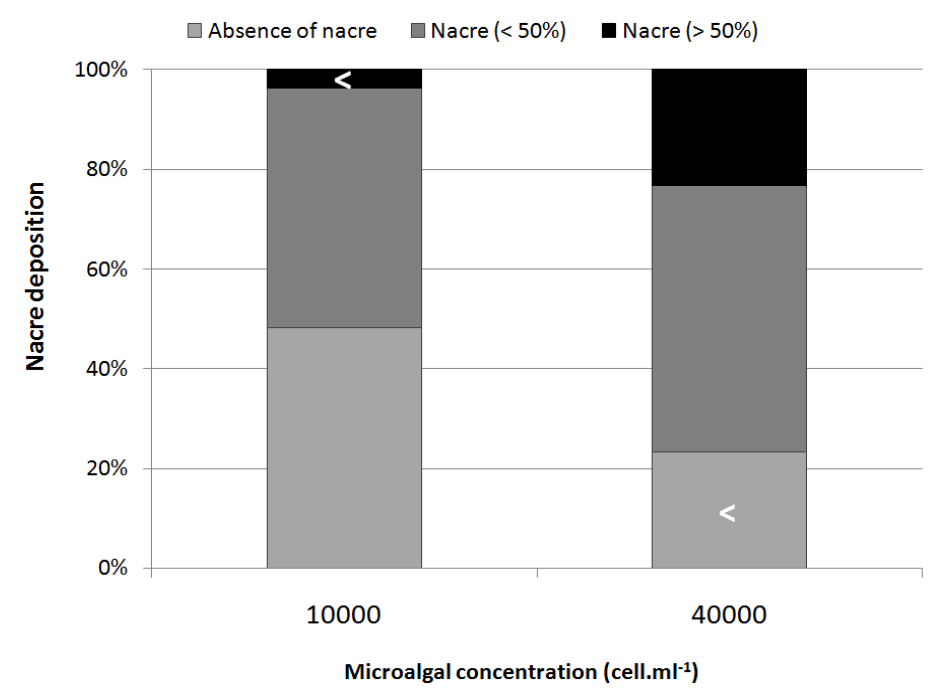

A. 2

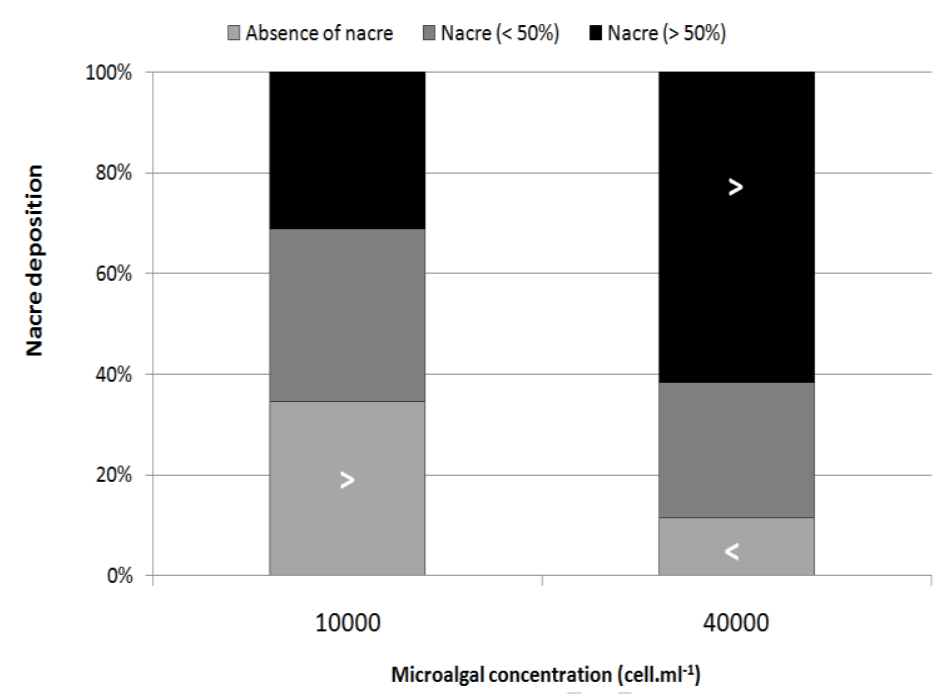

B. 1

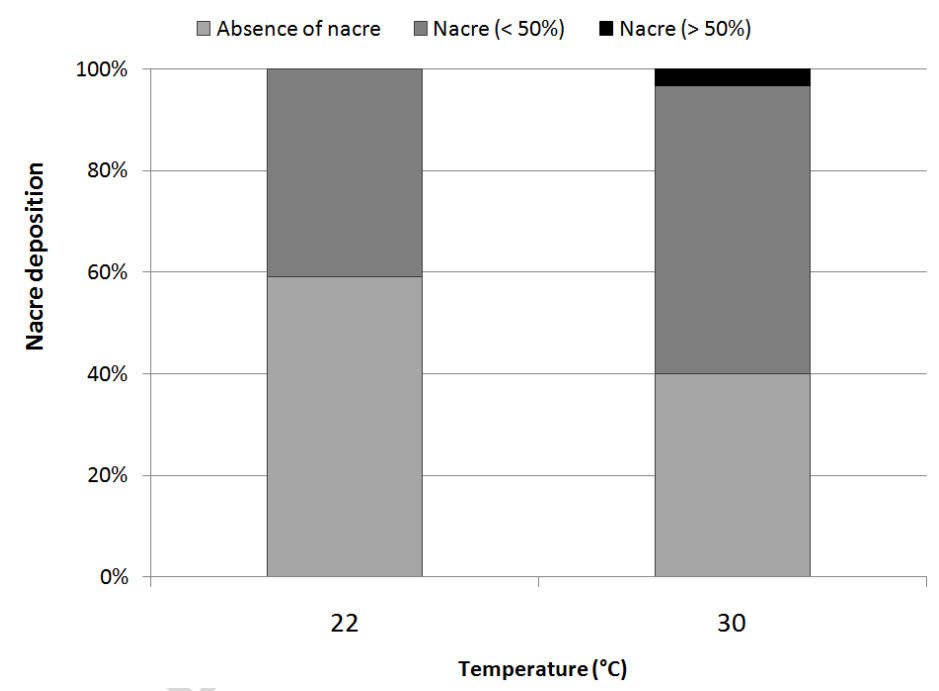

\section{B. 2}

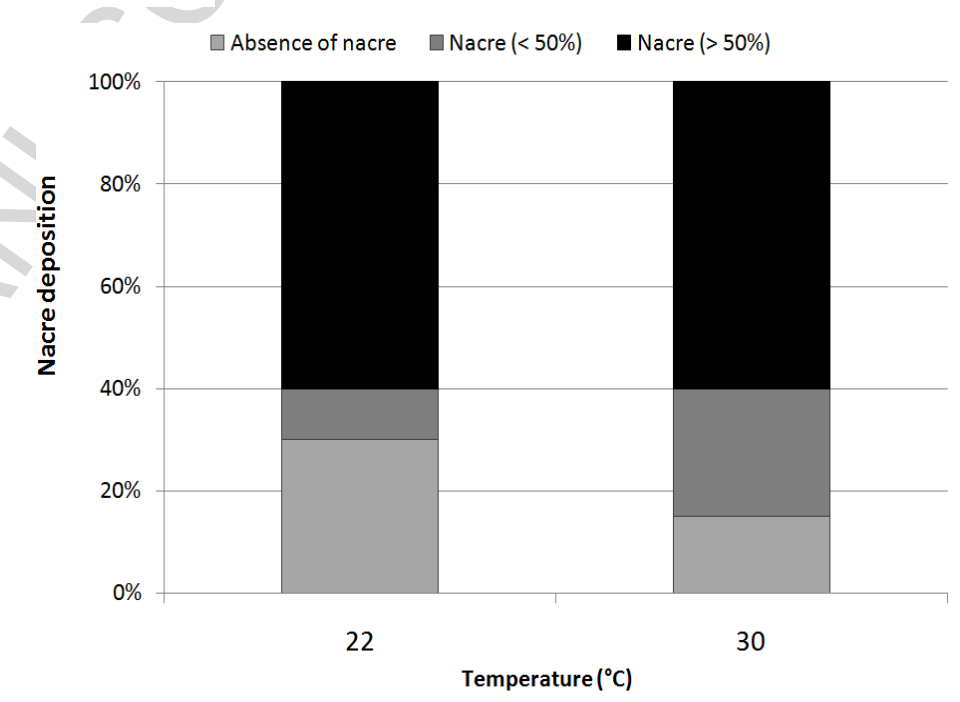

Fig. 5. 

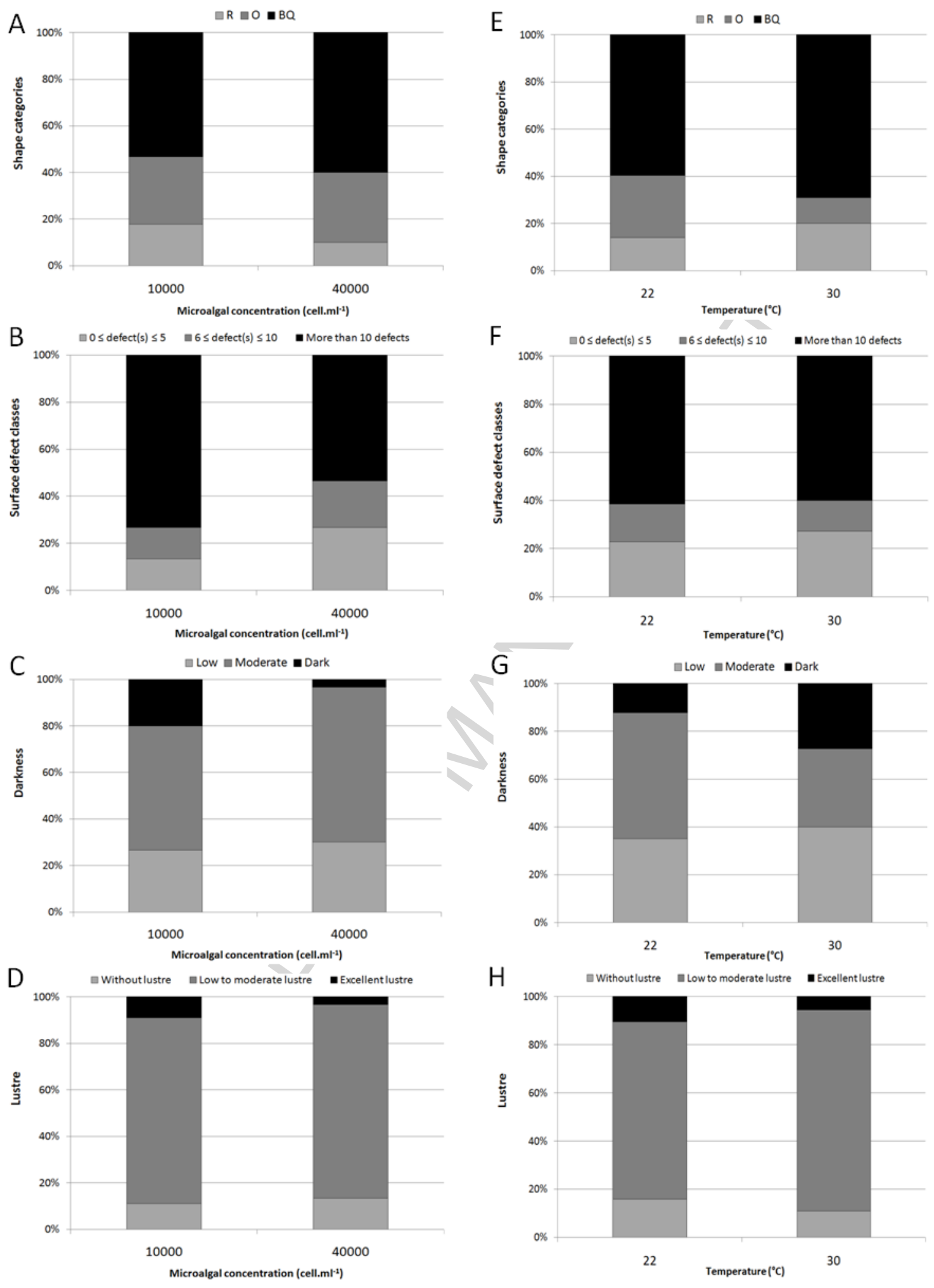

Fig. 6. 
A

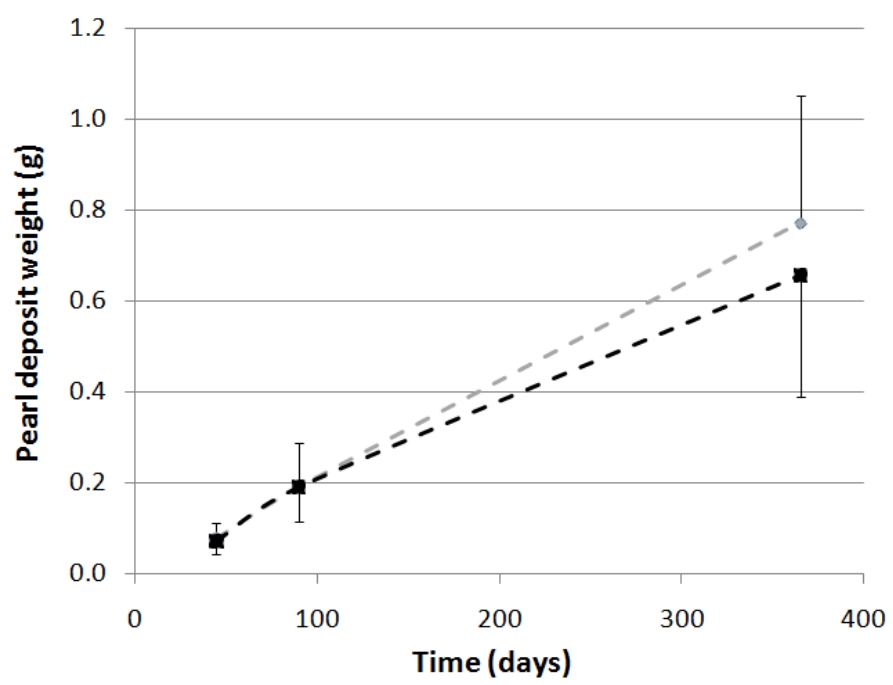

B

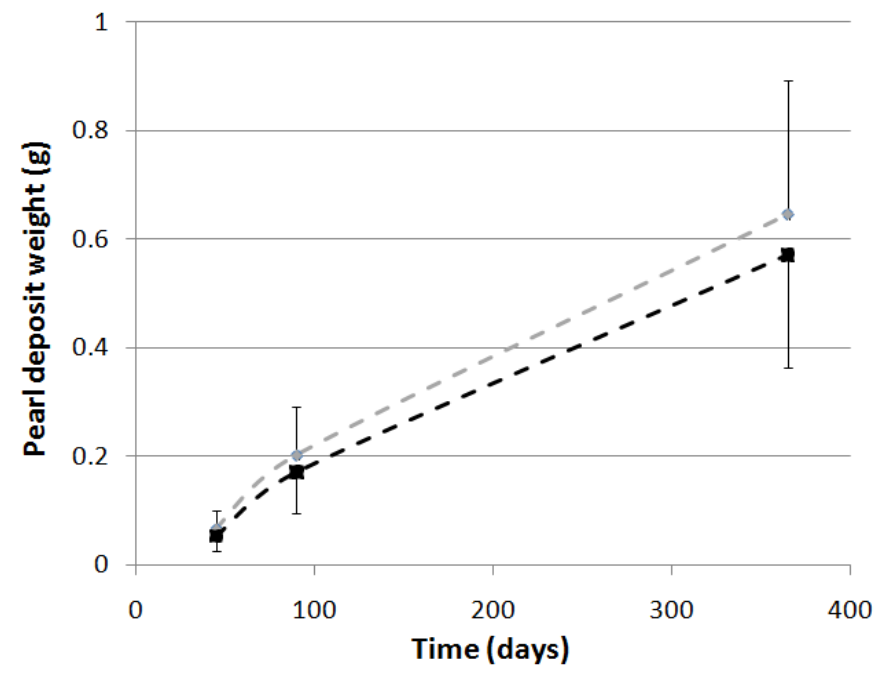

Fig. 7. 
Fig. 1. Experimental design: Number of pearl oysters preoperatively conditioned and grafted in experiments 1 and 2 and number of corresponding harvested pearl sacs and pearls (italics) at each sampling time.

Fig. 2. Mean Shell Deposit Rate (SDR, $\mu \mathrm{m} \cdot \mathrm{day}^{-1}$ ) inpearl oyster Pinctada margaritifera after 1month at different (A) microalgal concentrations and (B) temperatures. Each plot includes: mean ("+" cross in the box-plot), median (solid bar in the box-plot), $25^{\text {th }}$ to $75^{\text {th }}$ percentile represented in the rectangular box, $1.5 \times$ interquartile range (non-outlier range of the box whiskers), minimum and maximum values (extreme dots), and outlier values (outside box whiskers). Statistical analysis was done using (A) Student $t$ and (B) Mann-Whitney tests; *p< 0.05 and $* * \mathrm{p}<0.01(\mathrm{~N}=5$ per condition for each experiment $)$.

Fig. 3. Mean relative expression of genes coding proteins involved in the formation of the nacreous layer (Msi60, Pif177, and Pearlin), prismatic layer (Aspein and Prismalin14), and both (Nacrein), in mantle following a 1-monthconditioning period at different microalgal or temperature concentrations. (A) Different microalgal concentrations: 10,000 cells $\cdot \mathrm{mL}^{-1}$ (light grey) and 40,000 cells $\cdot \mathrm{mL}^{-1}$ (dark grey); and (B) different temperatures: $22^{\circ} \mathrm{C}$ (light grey) and $30^{\circ} \mathrm{C}$ (dark grey). Fold change means were calculated from five individual oysters/treatment. Y-axes are in the logarithmic scale. Error bars indicate standard deviations (SD); statistical analyses used Student $t$-tests (MSI60, Pif177, Pearlin, Aspein, and Nacrein) or Mann-Whitney tests (Prismalin14).

Fig. 4. Mean relative expression of genes coding proteins involved in formation of nacreous layers (MSI60, Pif177, and Pearlin), prismatic layers (Aspein and Prismalin14), and both (Nacrein) in pearl sacs formed from grafts from donor oysters 
preoperatively conditioned at different microalgal concentrations. (A) Different microalgal concentrations: 10,000 cells $\cdot \mathrm{mL}^{-1}$ (light grey) and 40,000 cells $\cdot \mathrm{mL}^{-1}$ (dark grey), at (A.1) 45 days, (A.2) 3 months, and (A.3) 12 months postgrafting. (B) Different temperatures: $22^{\circ} \mathrm{C}$ (light grey) and $30^{\circ} \mathrm{C}$ (dark grey), at (B.1) 45 days, (B.2)3 months, and (B.3) 12 months postgrafting. Fold change means were calculated from 20 individuals per treatment at each sampling time. Y-axes are in the logarithmic scale. Error bars indicate standard deviations $(\mathrm{SD}) ;{ }^{*} \mathrm{p}<0.05$ and $* * \mathrm{p}<0.01$

Fig. 5. Proportion of harvested pearls in different categories of nacre deposition with implanted grafts collected from donor oysters preoperatively conditioned at different microalgal concentrations and temperatures. Donors conditioned with (A) different microalgal concentrations: 10,000 and 40,000 cells $\cdot \mathrm{mL}^{-1}$ at (A.1) 45 days and (A.2) 3 months postgrafting; and (B) different temperatures: 22 and $30^{\circ} \mathrm{C}$ at (B.1) 45 days and (B.2) 3 months postgrafting. Number of harvested pearls is given in Fig. 1. > indicates a significantly higher number and $<$ a significantly lower number than expected between conditions $(\mathrm{p}<0.05$, Ftest).

Fig. 6. Proportion of harvested pearls with implanted grafts collected from donor oysters in different pearl quality categories 12 months postgrafting according to preoperative conditioning. Effect of donor preconditioning with 10,000 or 40,000 cells $\cdot \mathrm{mL}^{-1}$ on (A) shape (R: round, semi round; O: oval, button and drop; and BQ: semi baroque and baroque), (B)number of defects, (C) darkness, and (D) luster. Effect of donor preconditioning at 22 or $30^{\circ} \mathrm{C}$ on (E) shape, (F) number of defects, (G) darkness, and (H) luster. Number of harvested pearls is given in Fig.1. 
Fig. 7. Pearl deposit weight at different sampling times with grafts collected from donor oysters preoperatively conditioned at different microalgal concentrations and temperatures. (A) Different microalgal concentrations: 10,000 cells $\cdot \mathrm{mL}^{-1}$ (light grey) and 40,000 cells $\cdot \mathrm{mL}^{-1}$ (dark grey); and (B) different temperatures: $22^{\circ} \mathrm{C}$ (light grey) and $30^{\circ} \mathrm{C}$ (dark grey). Number of harvested pearls is given in Fig.1. 


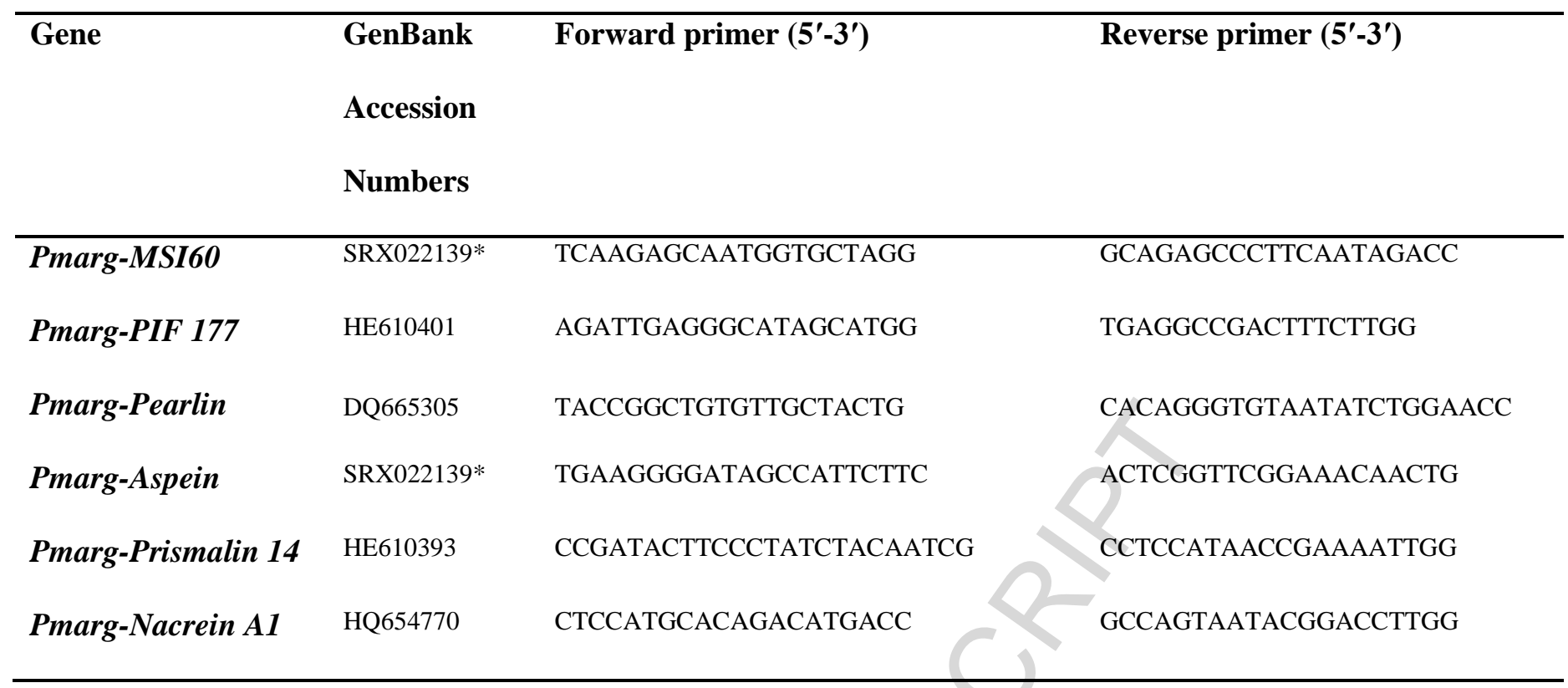

*SRA accession number; EST library published by Joubert et al.(2010)

Table 1. Forward and reverse primers used for the gene expression analysis. 


\section{A}

45 days postgrafting

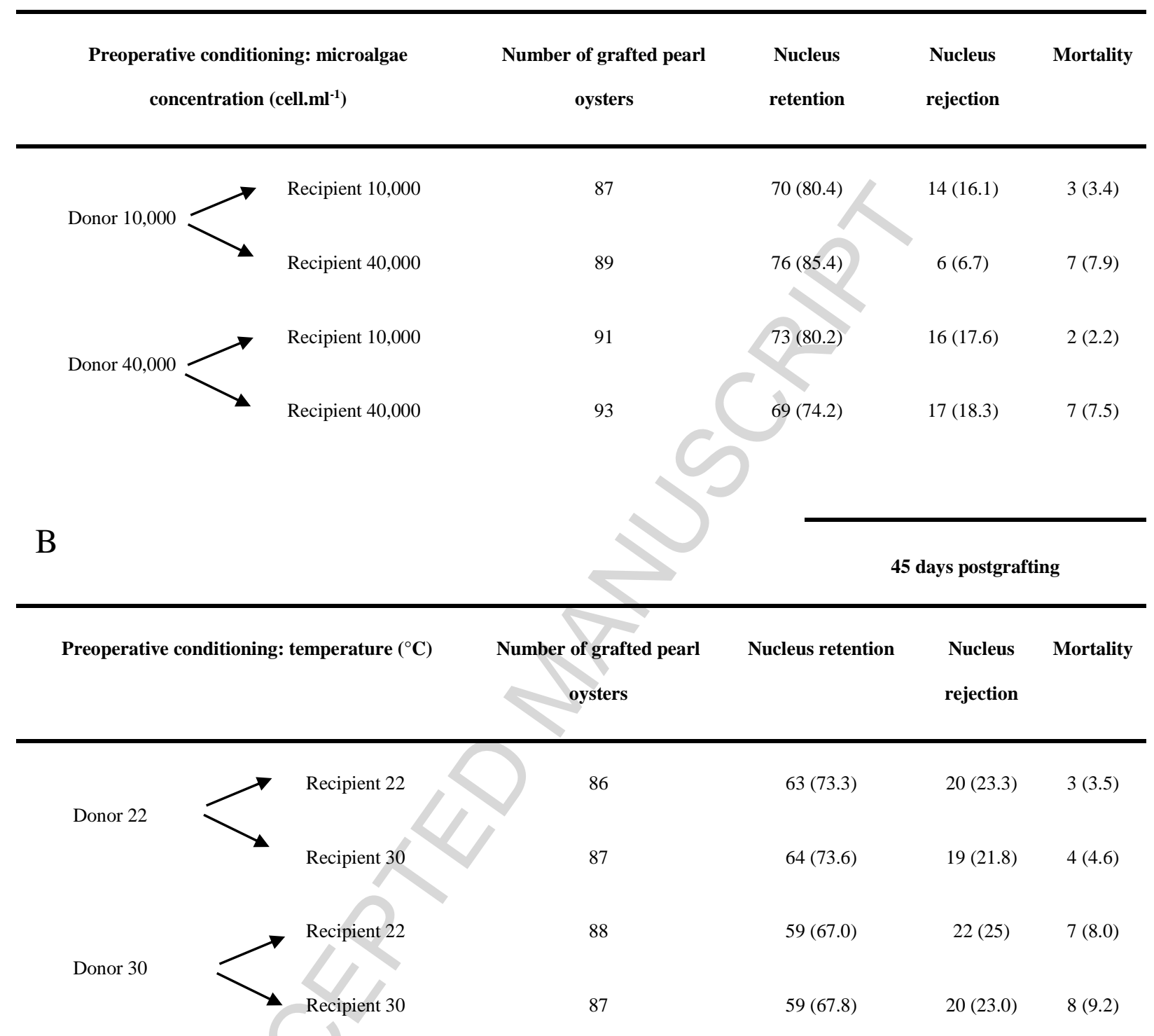

Table 2. Grafted pearl oysters Pinctada margaritifera at 45 days postgrafting 
A

Sampling time Variable associated with pearl weight Spearman's correlation coefficient $\quad p$-value

\begin{tabular}{|llcc|}
\hline 45 days & Donor oyster growth & -0.146 & 0.281 \\
\hline & Recipient oyster growth & $\mathbf{0 . 2 6 5}$ & $\mathbf{0 . 0 4 9}$ \\
\hline 3 months & Donor oyster growth & 0.007 & 0.961 \\
\hline & Recipient oyster growth & 0.151 & 0.265 \\
\hline 12 months & Donor oyster growth & -0.194 & 0.096 \\
\hline & Recipient oyster growth & $\mathbf{0 . 5 4 9}$ & $<\mathbf{0 . 0 0 0 1}$ \\
\hline
\end{tabular}

$\mathrm{B}$

\begin{tabular}{|llcc|}
\multicolumn{1}{c}{ sumpling time } & Variable associated with pearl weight & Spearman's correlation coefficient & p-value \\
\hline 45 days & Donor oyster growth & -0.158 & 0.33 \\
\hline & Recipient oyster growth & $\mathbf{0 . 5 7 4}$ & $\mathbf{0 . 0 0 0 1}$ \\
\hline 3 months & Donor oyster growth & -0.083 & 0.61 \\
\hline & Recipient oyster growth & $\mathbf{0 . 3 4 5}$ & $\mathbf{0 . 0 3}$ \\
\hline 12 months & Donor oyster growth & -0.06 & 0.528 \\
\hline & Recipient oyster growth & $\mathbf{0 . 4 3 1}$ & $<\mathbf{0 . 0 0 0 1}$ \\
\hline
\end{tabular}

Table 3. Correlation between pearl weight and both donor and recipient oyster growth at each sampling time. A : Microalgal concentration conditioning experiment. B : Temperature conditioning experiment. Spearman's coefficient correlation associated with significant p-value $(<\mathbf{0 . 0 5})$ are in bold. Number of harvested pearls is given in Fig.1. 


\section{Highlights}

- Donor oyster food level influences molecular biomineralization capabilities of pearl sacs

- Donor oysters fed at a high food level produced pearls with more nacre at early stages

- Recipient oyster preoperative temperature and food conditions did not affect pearl biomineralization 